\title{
ANÁLISE DIALÓGICA DO GÊNERO JORNALÍSTICO OMBUDSMAN
}

\author{
DIALOGIC ANALYSIS OF OMBUDSMAN PRESS SPEECH GENRE
}

\author{
Rosângela Hammes Rodrigues \\ Docente do Programa de Pós-graduação em Linguística - UFSC \\ Vinicius Valença Ribeiro \\ Mestre em Ciências da Linguagem - UNISUL ${ }^{1}$
}

\begin{abstract}
Resumo
Este artigo apresenta uma análise interpretativa do gênero do discurso ombudsman da esfera do jornalismo. Os dados de pesquisa compreendem as versões online do ombudsman, publicadas semanalmente, de dois jornais brasileiros, ambos com periodicidade diária: Folha de S. Paulo, da cidade de São Paulo (SP), e Jornal da Manhã, da cidade de Ponta Grossa (PR). O período de coleta ocorreu entre os dias 14 de dezembro de 2008 e 09 de janeiro de 2009, o que resultou na coleta de quatro ombudsman de cada jornal, totalizando oito enunciados do gênero. $\mathrm{O}$ trabalho tem como fundamentação teórica a concepção dialógica da linguagem do Círculo de Bakhtin, bem como seus estudos acerca dos gêneros do discurso. Para a análise, são seguidos os procedimentos metodológicos organizados por Rodrigues (2005), consonantes com a fundamentação teórica do Círculo. A fim de favorecer a compreensão do gênero, são propostas duas grandes abordagens, que se relacionam: análise da dimensão social e análise da dimensão verbal [dimensão da linguagem materializada]. Cada uma dessas abordagens possui seus desdobramentos analíticos separados em seções ao longo do trabalho. Finalmente, buscou-se realizar uma síntese de algumas regularidades do gênero que foram evidenciadas durante o estudo. Verificamos que o jornal onde o gênero se expressa e a esfera discursiva do jornalismo como um todo são os objetos de discurso do gênero; o endereçamento é ao leitor do jornal, ao passo que o autor do ombudsman busca atender ao que ele (leitor) reivindica, empenhando-se em um movimento dialógico de engajamento para com o leitor previsto/geral do gênero. Para tanto, o autor produz um acento de valor positivo ou brando, quando crítico, para o discurso do leitor e, ao mesmo tempo, um acento de valor negativo (ou um efeito de valor negativo), de um modo geral, para a cobertura jornalística objeto de discussão; há uma relação dialógica fortemente marcada entre leitor, jornal e autor, bem como a materialização das críticas dos leitores de modo implícito ou na forma de citação direta ou indireta na textualização do gênero; o projeto discursivo do gênero ombudsman está limitado pelo projeto ideológico/mercadológico da empresa jornalística. A crítica ao jornal e a defesa do leitor são permitidas pelo jornal desde que não determinem polêmicas em grau elevado capazes de desestabilizar os interesses comerciais da empresa jornalística.
\end{abstract}

Palavras-chave: Ombudsman. Gêneros do discurso. Jornal. Leitor. Análise dialógica do discurso.

\footnotetext{
${ }^{1}$ Participante do grupo de pesquisa Os gêneros do discurso: práticas pedagógicas e análise de gêneros. Grupo de pesquisa do Programa de Pós-graduação em Linguística da UFSC, coordenado pela professora Rosângela Hammes Rodrigues.
} 


\begin{abstract}
This article presents an interpretative analysis of ombudsman speech genre in journalistic sphere. The research data collected to its accomplishment comprises the online versions of two Brazilian newspapers ombudsman columns. Both have daily periodicity. The newspapers are: Folha de S. Paulo from São Paulo city in São Paulo state, and Jornal da Manhã from Ponta Grossa city in Paraná State. The columns are weekly published. The data period took place from December the $14^{\text {th }}$ to January the $9^{\text {th }}$, which resulted in the collection of four ombudsman of each newspaper, totalizing eight utterances of the genre. Bakhtin and his Circle's dialogic language conception, as well as his studies concerning speech genres, are the theoretical foundation for the research. In the analysis, the procedures organized by Rodrigues (2005), agreeable to the theoretical foundation, are applied. In order to favor comprehension, two related approaches of the genre are proposed: social dimension analysis; verbal dimension analysis [materialized language dimension]. Each one has its own analytic ramifications which are separated as sections along the work. Finally, it was tried to accomplish a synthesis of some genre regularities which were evidenced during the study. We verified that the newspaper in which the speech genre expresses itself and the journalistic sphere as a whole are the discourse objects of the genre; the address is to the readers while the ombudsman genre author tries to comply with them and with what they demand, establishing a dialogic movement of engagement with the genre's predicted/generic reader. For that, the ombudsman author produces a positive or soft sense value when the reader's discourse is criticized and, at the same time, produces (or seems to produce) a negative sense value to the press coverage as a whole, which is the discussion object. There is a dialogic relationship, strongly indicated, among reader, newspaper and author and the materialisation of the reader's implicit critique in the textual aspect of the genre which appears as a direct or an indirect quote. The discursive project of the ombudsman genre is limited by the ideological/business project of the press company. The critique to the newspaper and the support to the reader are permitted by the newspaper as long as these attitudes do not cause prolonged polemics which can offer the risk of instability to the business interests of the newspaper.
\end{abstract}

Keywords: Ombudsman. Speech genre. Newspaper. Reader. Dialogic Discourse Analysis.

\title{
1 INTRODUÇÃO
}

Como já destacado na introdução deste número da revista Working Papers em Linguística, a motivação para esta pesquisa surgiu a partir de debates e seminários realizados no decorrer da disciplina LIN 4002-078 Seminário de Especialidade: Teorias de Gêneros do Discurso, ministrada pela Professora Dr $^{\mathrm{a}}$. Rosângela Hammes Rodrigues no Programa de Pós-Graduação em Linguística da Universidade Federal de Santa Catarina durante o segundo semestre de 2008. Durante a realização da disciplina tivemos a oportunidade de tomar contato com as várias concepções de gêneros, as diferentes vertentes teóricas e seus autores. Buscamos, então, a partir da observação de suas peculiaridades teóricas e metodológicas, realizar pesquisa de gênero nesses diferentes enquadres, mas tendo como dados de pesquisa o mesmo gênero, o ombudsman. 
Em nosso artigo, o alicerce teórico para a análise do gênero ombudsman é a abordagem dialógica dos gêneros do discurso. Os fundamentos teóricos primordiais para sua realização correspondem à teoria dos gêneros do discurso do Círculo de Bakhtin e a sua visão dialógica da linguagem.

O artigo encontra-se dividido, além da introdução e conclusão, em outras três seções. Na segunda seção, trazemos o referencial teórico que embasa a análise realizada. Na terceira, os dados da pesquisa e os procedimentos metodológicos. Já os resultados de pesquisa são apresentados na quarta seção do artigo.

\section{FUNDAMENTOS TEÓRICOS}

Entender os gêneros do discurso sob a ótica do Círculo de Bakhtin requer a compreensão da gama de elementos que lhes são constitutivos. O Círculo não determina tais elementos como meras categorias separadas entre si e que depois de combinadas resultam no delineamento de sua noção de gênero. Esses elementos, por sua índole constitutiva, ainda que possam receber certa sistematização para fins didáticos e analíticos, necessitam serem entendidos sob o ponto de vista de uma relação mútua e de uma totalidade. Interação, discurso, dialogismo e enunciado, entre outros conceitos do Círculo, também exigem uma compreensão cujo ponto de partida é sua perspectiva dialógica e ideológica da linguagem. Para sua compreensão e interpretação eles não são abstraídos da esfera sócio-ideológica onde se constituem, da história e da cultura; logo, não se apartam dos sujeitos interlocutores. Assim sendo, antes de aprofundarmos a questão dos gêneros do discurso, teceremos um panorama a respeito dessa perspectiva que concebe a linguagem como ideológica, sociológica e dialógica.

Para o Círculo de Bakhtin, a concepção de língua se contrapõe à concepção teórica saussureana e de seus seguidores, cunhada como objetivismo abstrato na obra Marxismo e Filosofia da Linguagem (BAKHTIN [VOLOCHINOV] ${ }^{2}$, 1986[1929³]). Segundo o autor, do ponto de vista do objetivismo abstrato, como o termo enuncia, a língua, objeto dos estudos linguísticos, é tomada como um sistema autônomo, abstraído das condições sociais e de seus participantes, e que pode ser reduzida em unidades menores hierarquizadas. Bakhtin reconhece a validade e legitimidade do enfoque, mas, ao mesmo tempo, tal visão serve como contraponto para o entendimento de sua perspectiva dialógica, afiliada a outras concepções sobre a linguagem, e que vão compor um universo maior de pesquisa, denominado pelo autor de metalinguística (1997 [1929]). Em Estética da Criação Verbal, o autor aponta para a legitimidade dos estudos sob o ponto de vista abstrato da língua, desde que seus resultados sejam considerados na sua condição de abstração de uma parte concreta da linguagem e não como seu todo:

Por si mesma, essa abstração científica é perfeitamente justificada, mas sob uma condição: a de ser nitidamente compreendida apenas

\footnotetext{
${ }^{2}$ Neste artigo não discutiremos a polêmica questão da autoria de alguns dos textos do Círculo de Bakhtin, uma vez que não faz parte dos objetivos da pesquisa. Usaremos os termos Círculo de Bakhtin e Bakhtin para nos referirmos ao trabalho do grupo. As obras cuja autoria está sob discussão serão referenciadas seguindo a opção do tradutor do texto, com a indicação entre colchetes do segundo possível autor.

${ }^{3}$ A indicação da primeira publicação das obras tem como objetivo situar cronologicamente a época em que os estudos foram feitos e a época aproximada das correntes teóricas a que se refere o autor.
} 
como abstração e não ser apresentada como fenômeno pleno concreto e real; caso contrário, ela se transforma em ficção. (BAKHTIN, 2003 [1979], p. 273).

Ainda em Marxismo e Filosofia da Linguagem (BAKHTIN [VOLOCHINOV], 1986[1929]), o autor apresenta outra corrente teórica dos estudos da linguagem, que nomeia como subjetivismo individualista. Essa concepção define a língua unicamente como expressão do pensamento individual. A enunciação não requer um outro a quem seria orientada, como também por nenhum outro é determinada. Surge como produto da consciência individual e, por isso, de certo modo, finda também como outra forma de abstração, já que as relações sociais e ideológicas não exercem peso algum na enunciação.

No tocante à concepção dialógica da linguagem, a língua é inseparável da interação verbal e das condições sócio-históricas que a engendram. O material semiótico da língua aparece como recurso para a significação, ou melhor, a significação lhe é constitutiva, resultado dos processos interacionais situados historicamente; entretanto, esse material semiótico só se torna vivo (constituição dos sentidos) na comunicação discursiva real, impregnada de valores ideológicos. Pela linguagem nos posicionamos, concordamos, discordamos. Esses atos só podem ganhar corpo em relação a um outro. Concordar ou discordar implica sempre a rejeição ou engajamento com outras vozes, e isto só é possível por meio da interação verbal.

A concepção dialógica da linguagem se opõe ao objetivismo abstrato, porque para a primeira são levados em conta os sujeitos enunciadores, os usos que fazem da língua e as relações com o que é extralinguístico, isto é, a situação discursiva concreta. A língua é vista, então, como discurso, inseparável das relações e determinações sociais e do âmbito da história. Para o Círculo de Bakhtin, nas relações dos indivíduos enunciadores a língua não existe fora dessa perspectiva. Sua concepção distancia-se também do subjetivismo individualista, porque a enunciação é sempre uma réplica e, simultaneamente, ponto de partida para outras enunciações. Aquilo que se refrata, inevitavelmente, toma como referência algo que foi anteriormente apropriado, mesmo que essa nova refração, por um processo de individuação, suscite um desacordo. $\mathrm{O}$ ato de enunciar não estabelece relação com uma esfera espiritualista ou idealista. É produto da alternância entre os interlocutores na comunicação discursiva concreta.

Com efeito, a enunciação é o produto da interação de dois indivíduos socialmente organizados e, mesmo que não haja um interlocutor real, este pode ser substituído pelo representante médio do grupo social ao qual pertence o locutor. (BAKHTIN [VOLOCHINOV], 1986 [1929], p. 112).

A partir do que foi dito, tentaremos aprofundar aquilo que é concebido como dialogismo. De imediato, pode-se pensar no dialogismo como alternância de vozes sociais. Entretanto, corre-se o risco de se cair em um reducionismo do termo. Levantamos então a questão: em que amplitude de tempo e espaço essa alternância se concretiza? Por vezes, em seus escritos, Bakhtin se utiliza do termo diálogo, palavra polissêmica, e que, por isso, não é difícil de ser entendida como fala, conversa cotidiana, conversa transcrita, acordo entre duas pessoas, interação imediata. Os enunciados que tornam concretas e únicas essas situações, obviamente, possuem caráter 
dialógico. No entanto, o dialogismo em Bakhtin, que também envolve as situações de interação mais cotidianas, transcende uma simplificação. O próprio autor, em Marxismo e Filosofia da Linguagem, faz uma espécie de ressalva quanto ao emprego do termo diálogo:

O diálogo, no sentido estrito do termo, não constitui, é claro, senão uma das formas, é verdade que das mais importantes, da interação verbal. Mas pode-se compreender a palavra 'diálogo' num sentido amplo, isto é, não apenas como a comunicação em voz alta, de pessoas colocadas face a face, mas toda comunicação verbal, de qualquer tipo que seja. (BAKHTIN [VOLOCHINOV], 1986 [1929], p.123).

O princípio dialógico da linguagem estende-se a uma esfera bem mais ampla. Abarca as afiliações ou os confrontos de sentido que ocorrem desde o discurso interior, passando pelas expressões artísticas, até os enunciados das obras científicas e filosóficas. As relações dialógicas são relações entre um eu e um outro no sentido amplo desses termos. São relações de interação entre consciências, sistemas ideológicos e grupos sociais, isto é, compreendem um vínculo discursivo entre as diferentes esferas de atividade humana e entre suas posições axiologicamente distintas. As relações dialógicas perpassam então toda a heterogeneidade do meio social. Logo, o fluxo dialógico é ininterrupto e as interações verbais (ou mediadas por outro sistema semiótico) são sempre dialógicas. Um enunciado oferece pistas de outros enunciados, outras vozes que lhe são pregressas e futuras, conflitantes ou não, quanto a seus sentidos. Cada novo enunciado é sempre uma réplica de outros enunciados já-ditos e, simultaneamente, oferece as condições discursivas para um novo ato de responsividade, isto é, para outras réplicas que estão por vir (enunciados pré-figurados).

Bakhtin (2003 [1979], p. 323) chama a atenção para a impossibilidade dialógica entre as unidades da língua vista como sistema: “As relações dialógicas pressupõem linguagem, no entanto elas não existem no sistema da língua. Não são possíveis entre os elementos da língua. A especificidade das relações dialógicas requer um estudo especial”. Parecenos possível afirmar, então, que se o enunciado é produto da atividade histórica dos indivíduos e só por meio de uma abstração científica justificada como tal ele pode ser estudado, por exemplo, como oração, frase ou texto (como artefato, como estrutura), o que vale para a dialogicidade comum ao enunciado evidencia uma posição bem mais radical, a de que sua abstração é impossível, mesmo em um estudo linguístico bem justificado. Se não há sujeitos enunciadores se alternando entre as orações enquanto sistema da língua, não há, então, dialogicidade. Ao traçar um paralelo entre a linguística tradicional e a concepção dialógica, Bakhtin evidencia que a oração, a palavra e suas reduções em unidades menores são elementos da língua como sistema e o enunciado é a unidade concreta e real da comunicação discursiva.

Em Estética da Criação Verbal, mais precisamente no texto Os Gêneros do Discurso ${ }^{4}$, Bakhtin define o enunciado ${ }^{5}$ como a unidade real e concreta da comunicação discursiva,

\footnotetext{
${ }^{4}$ Manuscrito inacabado do autor, produzido entre 1952-1953. Esse e outros manuscritos foram publicados pela primeira vez em 1979.

${ }^{5}$ Na introdução do livro Estética da Criação Verbal (2003 [1979]), o tradutor evidencia que não existe, ao menos nessa obra, uma distinção realizada por Bakhtin entre enunciado e enunciação tanto no que se
} 
uma vez que nos enunciamos somente por meio de enunciados. Quando fala de comunicação discursiva, embora o autor não faça referência direta ao esquema de comunicação verbal indicado por Roman Jakobson (1970), hoje essa relação dialógica é realizada. Não obstante, notamos um distanciamento entre esses dois conceitos, pois Bakhtin não enxerga a comunicação como um esquema que, grosso modo, compreende um remetente, uma mensagem, um destinatário passivo, um contexto e um código. Por exemplo, dentro da situação contextualizada, real e concreta de interação, o receptor é entendido como o outro interlocutor e assume uma posição ativa e responsiva:

[...] o ouvinte, ao perceber e compreender o significado (lingüístico) do discurso, ocupa simultaneamente em relação a ele uma ativa posição responsiva: concorda ou discorda dele (total ou parcialmente) completa-o, aplica-o, prepara-se para usá-lo, etc.; essa posição responsiva do ouvinte se forma ao longo de todo o processo de audição e compreensão desde o seu início, às vezes literalmente a partir da primeira palavra do falante. Toda compreensão da fala viva, do enunciado vivo é de natureza ativamente responsiva (embora o grau desse ativismo seja bastante diverso); toda compreensão é prenhe de resposta, e nessa ou naquela forma a gera obrigatoriamente: o ouvinte se torna falante. (BAKHTIN, 2003 [1979], p. 271).

O enunciado, ao contrário das unidades da língua, só pode ser entendido levando-se em conta a situação concreta de enunciação. Ele surge da posição única e singular do indivíduo no fluxo da teia discursiva. É também único e irrepetível, ao contrário de um elemento da língua como sistema, como, por exemplo, a palavra e a oração, que podem ser repetidos. O enunciado tem sua dimensão semiótica, o que o determina como um construto que reivindica os recursos linguísticos para sua objetivação. Porém, esses recursos, na situação real da comunicação discursiva, já não são mais simplesmente unidades da língua como sistema. São elementos que passam a compor um todo de sentido, e, no momento da apreensão pelo interlocutor, não são percebidos ou assimilados como unidades da língua como sistema, mas como elementos do enunciado, com seus sentidos.

Qualquer enunciado possui os seus limites, isto é, um início e um fim. A cadeia discursiva dialógica nunca é interrompida, porque o fim de um enunciado é o início de outro enunciado, se não externamente verbalizado, ao menos como compreensão responsiva do discurso interior. O fim de um enunciado encerra sempre uma reivindicação de responsividade. Portanto, a alternância dos sujeitos enunciadores determina os limites do enunciado. Essa alternância é definida por Bakhtin (2003 [1979]) como a primeira peculiaridade do enunciado como unidade real da comunicação discursiva. $\mathrm{O}$ autor define a conclusibilidade específica do enunciado como sua segunda peculiaridade. A alternância é suscitada justamente porque existe a conclusibilidade do enunciado: “[...] essa alternância pode ocorrer precisamente porque o falante disse (ou

refere à produção do discurso oral quanto escrito: "Muito se tem falado de enunciação e enunciado na obra de Bakhtin. Neste livro, o autor emprega um só termo - viskázivanie - quer para o ato de emissão do discurso, que seria a enunciação, quer para um discurso já pronunciado e até um romance, que seria o enunciado. Portanto, para ele o discurso de um passado remoto, um texto filosófico ou a emissão de um discurso são viskázivanie. Ele associa também o termo à parole saussuriana, o que permite falar de enunciação” (Estética da Criação Verbal, 2003, p. XI da introdução). 
escreveu) tudo o que quis dizer em dado momento sob dadas condições” (BAKHTIN, 2003 [1979], p. 280, grifos do autor). Em certo momento da interlocução, aparecem os indícios de que o que estava sendo dito foi concluído. Somente na interação verbal esses indícios podem ser medidos. É daí que surge a possibilidade da posição responsiva, a partir da percepção de inteireza do enunciado.

Quais são então os elementos que determinam essa inteireza (conclusibilidade) ou o fim do enunciado para que aconteça a atitude responsiva? Bakhtin (2003 [1979] lista três elementos primordiais. O primeiro é a exauribilidade do objeto e do sentido ou exauribilidade semântico-objetal. O objeto, antes de tornar-se tema de um enunciado, é inesgotável, pois é suscetível de apropriação pelas mais diversas esferas da atividade humana e da comunicação discursiva. A partir do momento em que se torna tema de um enunciado, é cerceado pela atitude valorativa do autor, pelo seu horizonte axiológico, pelo ponto de onde parte o enunciado, pela sua ideia de como tratar esse objeto-tema e, simultaneamente, pela apreensão de como esse objeto-tema já foi tratado. Ele é envolvido pelo elemento expressivo, determinante para a escolha dos recursos linguísticos do enunciado, afastando qualquer possibilidade de neutralidade quanto àquilo que se enuncia.

O conteúdo semântico-objetal está intricadamente ligado ao segundo elemento determinante da inteireza do enunciado, definido por Bakhtin como o projeto discursivo ou vontade de discurso do falante. A intenção discursiva determina a escolha do objeto e o tratamento valorativo dado a ele. $O$ sujeito enunciador, situado sócio-historicamente, escolhe o que dizer de acordo com seu horizonte axiológico e de acordo com o interlocutor a quem seu enunciado se dirige. O enunciado é determinado não só pelos enunciados que o precederam, mas também pelas atitudes responsivas potenciais do interlocutor, mais ou menos calculadas e objetivadas (desejadas) pelo sujeito enunciador. Seu objeto do discurso é esgotado, limitado valorativamente segundo as possibilidades que essa limitação lhe oferece em relação ao que tem a dizer sobre ele e ao modo como quer ser entendido, apesar da relação com tudo o que já foi dito a seu respeito.

Finalmente, o terceiro elemento que delineia o todo do enunciado é o gênero do discurso, que é constitutivo dos dois elementos anteriores. Bakhtin (2003 [1979]) conceitua os gêneros do discurso como tipos relativamente estáveis de enunciados. A exauribilidade do objeto e do sentido e o projeto de discurso, bem como o estilo e a construção composicional do enunciado são determinados pelo campo da atividade humana para o qual um determinado gênero é comum. Esses inumeráveis campos onde atuam os indivíduos têm suas especificidades e condições de produção próprias, o que vai gerar também uma infinidade de gêneros do discurso:

Uma determinada função (científica, técnica, publicística ${ }^{6}$, oficial, cotidiana) e determinadas condições de comunicação discursiva, específicas de cada campo, geram determinados gêneros, isto é, determinados tipos de enunciados estilísticos, temáticos e composicionais relativamente estáveis. (BAKHTIN 2003 [1979], p. 266).

\footnotetext{
${ }^{6}$ Jornalística.
} 
O projeto discursivo se concretiza por meio de um gênero determinado pela esfera de atuação humana em que está inserido o enunciador, pelos temas comuns a essa esfera e pelas particularidades de seus participantes da interação. A subjetividade do enunciador não é apagada, mas é regulada e adequada ao gênero do discurso e coerente com sua intenção discursiva. Qualquer discurso é moldado por um gênero, pois, segundo Bakhtin (2003 [1979]), nós nos enunciamos somente através dos gêneros do discurso.

O mais alto grau de individualidade é manifestado no enunciado, o que Bakhtin (2003 [1979]) chama de entonação expressiva, sem que isto represente o desvanecimento da relativa normatividade comum ao gênero. Por entonação expressiva podemos entender o "colorido" dado ao enunciado e manifestado em um tom, que pode ser de alegria, ironia, humor, pesar, entre outros. A expressividade é outra peculiaridade do enunciado. Em outras palavras, a relação valorativa do enunciador com o objeto tratado (já valorado pelos enunciados já-ditos) como tema define as escolhas dos elementos linguísticos e sua organização no interior do enunciado a fim de configurar um tom de expressão. Bakhtin, no entanto, chama a atenção para mais três aspectos muito importantes no que diz respeito ao estilo. A escolha de uma palavra não é feita devido a um tom emocional/expressivo prévio que ela teria e que serviria muito bem à intenção discursiva. Ao contrário, é no todo do enunciado que a palavra ganha expressividade. Outro aspecto diz respeito aos enunciados que precedem um novo enunciado e tratam do mesmo tema ou de um tema similar. A apreensão do modo como foram feitas as escolhas dos recursos linguísticos nos enunciados pregressos (enunciados já-ditos), com o intuito de delinear um tom expressivo, propicia ao enunciador uma base de referência de como o objeto será tratado. Ele pode conflitar com o já-dito e sua expressividade, como também se engajar a ele. Esse processo torna-se determinante para a resposta potencial do interlocutor (enunciados pré-determinados, reação-resposta), cujo tom, favorável ou não, também se manifesta a partir das escolhas linguísticas. Finalmente, outro elemento determinante do gênero e da composição-estilística dos seus enunciados é o endereçamento. Todo gênero antecipa um destinatário típico, que exerce uma influência na composição de seus enunciados. $\mathrm{O}$ enunciador de um determinado gênero, na produção de seus enunciados, leva em consideração o que Bakhtin vai chamar de fundo aperceptivo do interlocutor. Esse fundo aperceptivo consiste no conjunto de valorações e conhecimentos do destinatário, que leva o enunciador a perguntas como: até que ponto o meu destinatário está ciente do que trato? Quais são suas possíveis opiniões sobre o tema? Qual o nível de conhecimento do meu destinatário sobre o tema? Qual sua posição social? Portanto, o endereçamento e, consequentemente, o fundo aperceptivo do destinatário exercem um peso determinante nas escolhas dos recursos linguísticos, definindo assim o estilo dos enunciados e seus gêneros.

Todo e qualquer gênero é indissociável de um estilo. Entretanto, existem graus da individualidade estilística. Concernente ao estilo individual, há gêneros mais propícios a essa composição e outros menos. Os gêneros literários, por exemplo, têm como um dos seus fins a evidência do estilo individual do autor. Já os documentos oficiais, por exemplo, devido ao seu alto grau de padronização, são muito pouco propícios à eclosão de um estilo individual, diríamos até, são impeditivos. Bakhtin destaca essa característica ao considerar o estilo individual como, geralmente, um acontecimento periférico na maioria dos gêneros: 
Na maioria dos gêneros discursivos (exceto nos artístico-literários), o estilo individual não faz parte do plano do enunciado, não serve como um objetivo seu, mas é, por assim dizer, um epifenômeno do enunciado, seu produto complementar. (BAKHTIN, 2003 [1979], p. 266).

Ainda em Os Gêneros do Discurso, Bakhtin diferencia dois grandes grupos de gêneros: os gêneros primários e os secundários. Os primeiros são caracterizados como simples e pertencentes ao plano da comunicação imediata, ou seja, às esferas da vida cotidiana. Os diversos tipos de diálogos face a face, a carta, a conversa de salão são exemplos de gêneros primários. Já os gêneros secundários são de natureza mais complexa, também chamados de gêneros ideológicos no sentido estrito do termo, pois são produzidos nos planos dos sistemas ideológicos constituídos e formalizados, ou seja, no domínio das esferas secundárias. Para esses gêneros predomina a modalidade escrita, o que denota um caráter também documental desses gêneros. São exemplos de gêneros secundários o romance, os diversos gêneros dos trabalhos científicos, entre outros. Para o autor, a diferença entre os dois grandes grupos de gêneros não é funcional, mas ideológica: os primários constituem-se no âmbito das ideologias do cotidiano e os secundários no âmbito das ideologias formalizadas e sistematizadas. Ainda, a diferenciação não significa fronteiras absolutas entre eles, como se fins diferentes entre os dois grupos lhes impusessem uma separação perpétua. Há entrecruzamentos. Os gêneros secundários assimilam uma série de características de gêneros primários, que vão delinear a sua constituição. Os gêneros primários, por sua vez, no interior de um enunciado de um gênero secundário, perdem as suas relações com a esfera do cotidiano para se tornarem elementos do gênero secundário, pois passam a fazer parte do todo de sentido deste gênero. O mesmo ocorre com os gêneros primários, que podem reelaborar outros gêneros do discurso.

A partir desses fundamentos teóricos iniciais analisaremos o gênero ombudsman.

\section{DADOS DA PESQUISA E ROTEIRO DE ANÁLISE}

Para a efetivação da abordagem sociodialógica do gênero ombudsman foram escolhidos como dados de pesquisa as versões online das colunas ${ }^{7}$ do ombudsman ${ }^{8}$ de dois jornais brasileiros de circulação diária: Folha de S. Paulo e Jornal da Manhã. O primeiro jornal é uma publicação diária de circulação nacional da cidade de São Paulo, estado de São Paulo. O segundo jornal é uma publicação da cidade de Ponta-Grossa, estado do Paraná. Sua abrangência, além da cidade de Ponta-Grossa, compreende outros vinte e um municípios da região em que está localizada a cidade.

O período de coleta de dados se realizou entre os dias 14 de dezembro de 2008 e 09 de janeiro de 2009. Foram analisadas quatro colunas de cada um dos jornais. Como na versão impressa, a coluna do ombudsman da Folha de S. Paulo em sua versão online é

\footnotetext{
${ }^{7}$ Estamos tomando o termo coluna neste trabalho não como um gênero, mas como um espaço físico fixo dentro do jornal onde são publicados textos de determinado gênero, como é o caso do gênero ombudsman (ou coluna do ombudsman).

8 A coluna do ombudsman do Jornal da Manhã em sua versão online é chamada de Espaço da Ombudsman. Ainda, é denominada e arquitetada (na seção onde se insere) como um blog.
} 
publicada semanalmente, aos domingos, embora a coluna do dia 14 de dezembro (domingo) tenha sido publicada somente no dia 15 (segunda), às $14 \mathrm{~h} 30 \mathrm{~min}$, devido a problemas de software, conforme aviso da própria Folha de S. Paulo. O Jornal da Manhã apresenta a versão impressa da coluna do ombudsman semanalmente, também na sua edição de domingo. No entanto, a versão online não obedece a essa regularidade. Os textos são postados em dias diferentes. O jornal avisa sobre esse procedimento. Durante o período de coleta, a coluna desse jornal não manteve um dia definido da publicação em versão online. Além disso, o período de uma semana foi excedido até ser publicada uma nova coluna.

As colunas do jornal Folha de S. Paulo foram coletadas nos dias: 15 de dezembro de 2008 (a coluna saiu com a data da publicação impressa de 14 de dezembro de 2008); 21 de dezembro de 2008; 28 de dezembro de 2008; 04 de janeiro de 2009. Por sua vez, as colunas do Jornal da Manhã foram coletadas nos dias: 14 de dezembro de 2008; 21 de dezembro de 2008; 30 de dezembro de 2008; 09 de janeiro de 2009. As duas primeiras foram publicadas em dias de domingo, enquanto as duas últimas foram publicadas em uma terça-feira e uma sexta-feira, respectivamente.

Apesar das diferenças de circulação já destacadas acima e das peculiaridades do hipertexto, por conta do suporte virtual, quanto ao conteúdo e à construção do texto, as versões online das colunas são idênticas às suas respectivas versões impressas.

A fim de manter a consonância entre os fundamentos teóricos e a realização da análise do gênero ombudsman, baseamo-nos nos procedimentos definidos por Rodrigues (2005) para a análise dos gêneros, fundamentados na noção de gênero do Círculo de Bakhtin, tal como em sua concepção dialógica da linguagem.

O gênero ombudsman compõe o campo da atividade jornalística. O primeiro momento de contextualização do gênero implica, então, o estabelecimento de relações com sua esfera social. Esse procedimento metodológico se justifica porque, a partir de uma perspectiva dialógica da linguagem, os enunciados não devem ser desvinculados do âmbito da atividade humana em que são produzidos. Os tipos de enunciados relativamente estáveis, isto é, os gêneros do discurso, são também delimitados axiologicamente pelo período histórico e pelas atividades humanas. Assim, refletem e refratam certa estabilidade valorativa de uma determinada esfera da atividade humana em uma dada época histórica.

Em seguida, a análise incide sobre a dimensão social específica do gênero. O foco principal é a observação de seus horizontes temporal e espacial. Para essa tarefa, apoiamo-nos na ideia de cronotopo delineada por Bakhtin. Embora, para o autor, as dimensões de tempo e espaço sejam indissociáveis em termos pragmáticos, o procedimento de análise adotado propõe a separação em horizontes distintos com o fim de favorecer a compreensão da pesquisa.

A abordagem dos horizontes temporal e espacial envolve também a análise:

a) Da alternância entre interlocutores, primeira peculiaridade do enunciado segundo Bakhtin, isto é, quem participa da interação; 
b) Do endereçamento e do fundo aperceptivo, que englobam certo conhecimento do autor e leitor e propiciam algumas condições de antever características e posições valorativas; trata-se do horizonte axiológico do gênero.

c) Da autoria dentro dos limites da produção e circulação do gênero.

Em seguida, considerando a análise da dimensão social do gênero, passamos a análise de sua dimensão verbal. Observamos os elementos seguintes, considerando o horizonte temático do gênero e suas implicações:

d) O objeto do discurso;

e) A dialogicidade entre os enunciados do gênero e outros enunciados observados - a quê ou a quem eles respondem;

f) A posição valorativa do autor em relação a esse objeto-tema e, consequentemente, os sentidos que ele busca produzir a partir daquilo do que ele trata - como ele responde a outros enunciados. A posição valorativa, enquanto discurso, está inserida na cadeia dialógica e, portanto, dialoga, positiva ou negativamente, com outras vozes que podem ser enquadradas pelo autor em movimentos dialógicos.

g) O projeto ou vontade do discurso, isto é, a finalidade do enunciador ao enunciar, a partir do gênero. O projeto do discurso é, por isso, o que determina a escolha do objeto do discurso.

\section{ANÁLISE DO GÊNERO OMBUDSMAN}

Considerando os procedimentos/passos metodológicos descritos na seção anterior, apresentamos a análise de algumas das regularidades do gênero ombudsman, distribuídas em respectivas subseções: a constituição do gênero na esfera jornalística; o horizonte espacial e temporal; os interlocutores/participantes da interação; o endereçamento e o fundo aperceptivo: o leitor previsto; a autoria; o horizonte temático; as relações dialógicas; e o projeto discursivo.

\subsection{O objeto de pesquisa: considerações históricas sobre a constituição do gênero na esfera jornalística}

A polissemia em torno da palavra ombudsman é facilmente percebida pela enumeração de alguns elementos que a significam: o cargo/profissão ombudsman ${ }^{9}$; o autor do gênero (no caso de um estudo sociodialógico como o presente); a coluna jornalística que materializa o gênero; o gênero propriamente dito. A atribuição do termo relaciona-se

\footnotetext{
${ }^{9}$ Optamos por nos referir ao gênero por meio do termo em itálico: "ombudsman". Ao longo do trabalho também mantemos esse mesmo termo quando nos referimos ao autor do gênero: "coluna do ombudsman" ou "ombudsman" (autor). Já quando a referência for somente ao cargo/profissão, a grafia segue normalmente: "ombudsman”. Quando nos reportarmos ao termo metalinguisticamente será usado o recurso de sublinhar: "o termo ombudsman/ a palavra ombudsman". Quando o termo aparecer em citações, seguiremos a opção do autor, com exceção dos casos de concordância e gênero do termo.
} 
primeiramente ao cargo, surgido na Suécia. Segundo Amaral (1993, p. 22), as suas raízes estão no século XVI, quando surge nesse país o grande senescal, que era um "[...] funcionário do rei encarregado de exercer o controle da atividade dos juízes do Reino sueco". Posteriormente, a função manteve-se no campo jurídico, mas também migrou para a esfera administrativa. Nesse tempo, o nome dado ao encarregado pelo controle da administração era justitiekansler. Já no século XIX, a constituição sueca de 1809 contribuiu para o início da consolidação do cargo no país com a introdução do justitieombudsman (ombudsman de justiça), com as mesmas responsabilidades sobre a esfera administrativa e judiciária. Pelo que percebemos, com o tempo, o termo sofreu uma redução para somente ombudsman. A palavra, de origem nórdica, é resultante da junção do termo ombud, que significa representante, procurador, com a palavra man homem - e não varia em número e gênero sendo, portanto, um equívoco falar em ombudswoman (VISMONA, 2000).

A função apresenta algumas variações e recebe outras denominações, mas a essência da atividade, voltada à defesa dos direitos individuais perante as instituições, permanece. Nos países hispânicos, o ombudsman é chamado de defensor del pueblo; na França, Médiateur; e em Portugal, Provedor de justiça. Nas corporações e na esfera pública brasileira, é mais conhecido como ouvidor. A função apresenta também suas características próprias no país. Conta, inclusive, com uma associação, a ABO Associação Brasileira de Ouvidores/Ombudsman -, criada em 1995.

No Brasil e em outros países, a atividade do ombudsman se estendeu consideravelmente. Ainda na Suécia, além do ombudsman para os assuntos públicoadministrativos, judiciários e militares, surgiu a profissão direcionada aos direitos dos consumidores, à liberdade econômica e à fiscalização da imprensa. Em várias partes do mundo, a figura do ombudsman pode ser encontrada nos sistemas bancário, universitário e mesmo no sistema penitenciário. Está presente também no interior das grandes corporações. É, sobretudo, esse lugar de atuação que nos remete à atividade do ombudsman na iniciativa privada e, no caso específico deste trabalho, na imprensa. No caso da iniciativa privada em sentido amplo, a experiência brasileira contou com a participação do ombudsman interno, aquele responsável, entre outras funções, pelo apaziguamento dos conflitos entre funcionários de diversos níveis hierárquicos no interior de uma empresa. A função não se limitou ao funcionamento interno. Simultaneamente a essa modalidade do cargo, desenvolveram-se as ouvidorias dispostas a acolher reclamações dos clientes ou dos consumidores dos produtos de uma empresa.

Como também são empresas, muitos jornais implantaram a função em seu quadro de atividades, com a especificidade de que o ombudsman não viesse a ser uma figura anônima. O ombudsman da empresa jornalística geralmente tem nome e histórico divulgados, além da particularidade maior de produzir uma coluna no jornal, ou seja, um discurso que se constituiu em um gênero específico na esfera do jornalismo. Sobre isso, há uma semelhança com o ombudsman sueco da esfera pública, que, segundo Mendes (2002), na atualidade, produz um relatório anual dos casos mais importantes que foram investigados:

Este espaço para a crítica pública para o ombudsman de governo sueco se assemelha às colunas dos ombudsmans [sic] de imprensa, publicadas nos jornais onde trabalham. É uma semelhança muito 
importante. Os ouvidores de imprensa gostam de se diferenciar de outros tipos de ombudsmans [sic] por fazerem a crítica da mídia, mas o exemplo sueco mostra que a crítica não é privilégio deles. (MENDES, 2002, p.24).

É interessante notar que no âmbito do jornalismo impresso manteve-se o termo original ombudsman, enquanto nas outras esferas da atividade humana em que atua esse profissional, a nomeação sofreu variações.

Há divergências quanto ao pioneirismo da implantação do ombudsman de imprensa. Três jornais reivindicam a posição: o japonês Asahi Shimbum e os americanos Louisville Courier-Journal e Louisville Times. O jornal japonês abriu espaço para algo parecido com o ombudsman em 1922. No entanto, questiona-se a legitimidade da função, pois os críticos apontam a considerável falta de independência do profissional que ocupou o cargo na época. Já os dois jornais americanos implantaram o ombudsman em 1967.

No Brasil, a primeira experiência com o ombudsman de imprensa se deu no jornal Folha de S. Paulo, em 1989, com Caio Túlio Costa. Posteriormente, outros jornais adotaram a função, como, por exemplo: A Notícia Capital (SC); O Povo (CE); Folha do Povo (MS); Diário do Povo (Campinas - SP); Nosso Bairro (Campos - RJ). Alguns desses veículos tiveram uma rápida experiência com o ombudsman, que depois se extinguiu. Mendes (2002) ainda chama a atenção para o fato de que nem sempre os profissionais ombudsman mantiveram uma coluna nos jornais, como foi o caso do jornal O Dia (RJ). O ombudsman também foi adotado em outros meios de comunicação além dos jornais, como foram os casos da revista Imprensa e da rádio O Povo/Jovem Pan do Ceará.

Como em um estudo sociodialógico a autoria é elemento constitutivo do gênero, podemos afirmar que o profissional ombudsman também é um autor do gênero da esfera do jornalismo (não mais a atividade profissional, interna à empresa), que recebe a mesma denominação.

O gênero ombudsman é bem mais comum nos jornais impressos. A coluna que no jornal comporta o gênero, geralmente também recebe o mesmo nome e com ele se confunde. As tênues fronteiras entre coluna e gênero quanto à denominação existem, entre outros aspectos, devido à inserção do gênero no jornal, que tem, por sua vez, como uma das suas divisões, as próprias colunas (encontramos outras divisões, como, por exemplo, os cadernos e as editorias). Este é o espaço do jornal que materializa o gênero. Logo, percebemos a polissemia do termo ombudsman na esfera jornalística, pois refere-se tanto ao autor do gênero, à coluna em que se materializa o gênero no jornal, ao próprio gênero (que recebe a denominação da autoria ) e, ainda, aos textos/enunciados do gênero (Você leu nesta semana o ombudsman do jornal $X$ ?).

Com a convergência dos meios de comunicação para o ambiente virtual, o jornal passou a ocupar um espaço importante nesse novo modo de interação. O gênero ombudsman possui o seu espaço nas versões online dos jornais, como demonstram as modalidades online dos jornais O Povo, do Ceará; da Folha de S. Paulo, e do Jornal da Manhã, de Ponta Grossa, esses dois últimos provedores de nossos dados de pesquisa. 


\subsection{O horizonte temporal e espacial}

No primeiro momento da análise, o que fundamenta a observação do horizonte temporal e espacial é o conceito de cronotopo de Bakhtin. Segundo o autor, o produtor/autor de um enunciado produz um recorte acerca de seu objeto, exerce um distanciamento e, nesse processo, ocupa um lugar único (eventicidade do enunciado). Ainda assim, sua produção é determinada pelas instâncias maiores de tempo e de espaço. Esses horizontes circunscrevem sua posição. O seu distanciamento não pode ser tamanho a ponto de se elevar sobre as dimensões histórica, social e cultural. Ele não excede a vida enquanto evento maior. "O ponto de vista é cronotópico e abrange tanto o elemento espacial quanto o temporal. A isto se vincula imediatamente o ponto de vista axiológico [...].” (BAKHTIN, 2003[1979], p. 369).

Na análise do cronotopo, a periodicidade, que pode ser considerada - além das questões históricas da constituição do gênero na esfera jornalística (abordadas na seção anterior) como um dos elementos da temporalidade imediata, é o primeiro aspecto a ser observado. Assim como a versão impressa, a versão online do Jornal da Manhã e da Folha de S. Paulo é de periodicidade diária. No entanto, a coluna do ombudsman de ambos possui periodicidade diferente em relação aos próprios jornais. As duas versões da coluna do ombudsman da Folha de S. Paulo são publicadas semanalmente, aos domingos. O Jornal da Manhã apresenta essa mesma periodicidade para a versão impressa da coluna, mas permite variar os dias de publicação da versão online. Durante o período de coleta dos dados, as duas primeiras colunas coletadas saíram aos domingos, enquanto as duas últimas saíram em dias diferentes da semana. Em observações posteriores ao período de coleta, verificamos os arquivos das colunas do ombudsman disponibilizados pelo Jornal da Manhã em seu site e percebemos que os textos publicados nos dias da semana durante o período de coleta estavam com as datas dos domingos dos meses desse período - dezembro de 2008; janeiro de 2009 -, o que nos levar a supor uma "arrumação" das datas por parte do jornal. Pressupomos, então, que o jornal ou objetiva evidenciar uma regularidade da publicação online da coluna, ou trata-se, simplesmente, de um critério de organização, embora seja avisado aos leitores que a versão online não segue a mesma regularidade da versão impressa. Ressaltamos, no entanto, que apesar das publicações em dias da semana diferentes para a versão online, o Jornal da Manhã, assim como a Folha de S. Paulo, manteve quatro ${ }^{10}$ publicações do gênero durante o mês de dezembro de 2008.

Por envolver posições valorativas correspondentes a ressalvas, críticas e elogios sobre os discursos tratados nos jornais, o gênero mantém uma relação dialógica de dependência com a publicação maior em que está inserido, o jornal. Este pode existir sem o ombudsman, mas o contrário não é verdadeiro. Os autores acercam-se de diversos assuntos já publicados e do tratamento dado a eles. Isso justifica a periodicidade do gênero, que não é diária, como o são os gêneros notícia, editorial e artigo assinado, por exemplo. Dada a sua função no jornal, que é analisar e comentar "o que se passa”, o intervalo de uma semana é o período em que são observados os objetos e os sentidos do discurso enunciados nos outros gêneros que compõem o jornal como um todo. Além

\footnotetext{
${ }^{10}$ Incluindo as publicações on-line do ombudsman de ambos os jornais do dia 07de dezembro de 2008 , somamos quatro publicações nesse mês. No entanto, os ombudsman (enunciados) desse dia não fazem parte dos dados de pesquisa.
} 
dessa dialogicidade com o jornal, há outra dialogicidade relevante para a periodicidade do gênero ombudsman, que diz respeito à posição responsiva ativa dos autores em relação aos comentários, sugestões e críticas dos leitores. Como no caso da espera pelas notícias, reportagens, artigos assinados, entre outros enunciados do jornal, é preciso um período de tempo para observar a posição responsiva ativa dos leitores e o grau de relevância deflagrado pelos temas abordados pelo jornal na semana. Em síntese, podemos dizer que existem dois movimentos dialógicos importantes na constituição da periodicidade do gênero: a apreensão, por parte dos autores do ombudsman, do que é discursivizado pelo jornal e pelos leitores e a posição responsiva ativa dos próprios autores a respeito dos discursos do jornal e dos leitores. Suas réplicas em relação ao posicionamento do jornal e dos leitores, provavelmente, não devem exceder também certo prazo, uma semana, o que poderia torná-las descompassadas em relação ao conteúdo abordado e, por isso, com pouca ressonância. Embora o ombudsman não tenha a mesma periodicidade diária do jornal pelos motivos que já apontamos, a profusão de informação do segundo não permite ao autor do primeiro prazos muito elásticos. Ao contrário, exige uma posição responsiva ágil nos limites de uma semana.

Outra particularidade que parece também ser determinante para a periodicidade semanal do ombudsman é a presença de subseções, na textualização do próprio gênero, sobre os assuntos mais comentados durante a semana pelos leitores. Essas subseções são identificadas por subtítulos. No Jornal da Manhã, a subseção é identificada pelo subtítulo Assuntos mais comentados durante a semana pelos leitores. Na Folha de S. Paulo, o subtítulo é Assuntos Mais comentados da Semana. Nas subseções, os assuntos mais comentados são apenas listados. No entanto, a exposição do que foi mais comentado pelos leitores é fixa e compõe o próprio gênero, o que força os seus autores a manter um prazo. Nas figuras 1 e 2, podemos observar a composição das subseções na textualização do gênero:

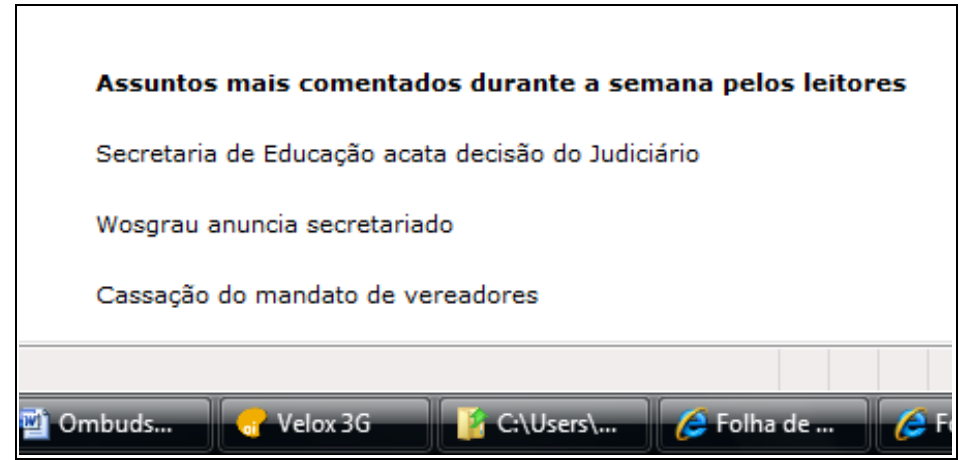

FIGURA 1. Subseção intitulada Assuntos mais comentados durante a semana pelos leitores e listagem dos assuntos - Jornal da Manhã - Espaço da Ombudsman ${ }^{11}$, de 21 de dezembro de $2008^{12}$.

Fonte: http://www.jmnews.com.br/index.php?SETOR=COLUNA\&CID=89\&POST=39282)

\footnotetext{
${ }^{11}$ A flexão para o feminino é uma opção do jornal. É desse modo que está citado no veículo.

${ }^{12}$ É preciso ressaltar que essa lista não representa links. Clicando em cima, nada é acessado. É somente uma listagem dos assuntos, embora o ato de listar, ainda que não traga comentários, seja, por si só, uma posição axiológica.
} 


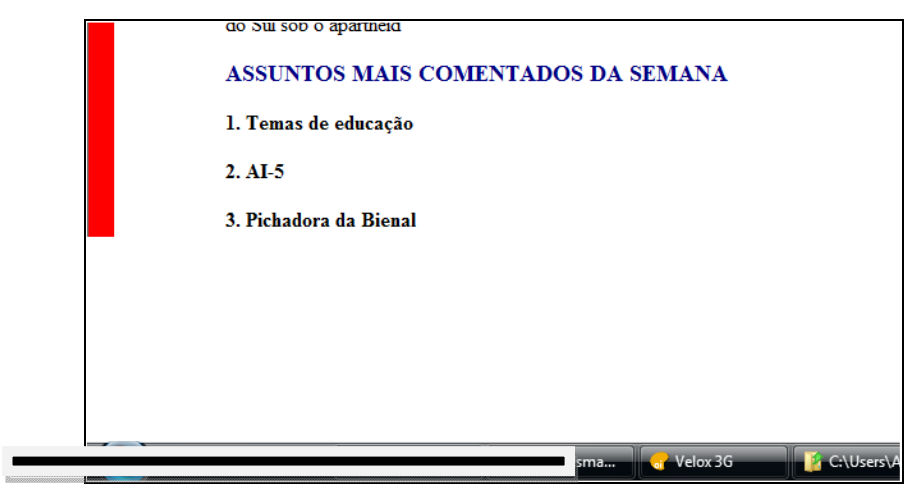

FIGURA 2. Subseção intitulada Assuntos Mais Comentados da Semana e listagem dos assuntos - Folha de S. Paulo - ombudsman de 21 de dezembro de $2008^{13}$.

Fonte: http://www1.folha.uol.com.br/fsp/ombudsma/om2112200803.htm

Os objetos dos discursos e dos sentidos e a periodicidade definem a temporalidade do jornal diário impresso. Os objetos dos discursos e dos sentidos são determinantes para a periodicidade, porque os primeiros envolvem acontecimentos de vários campos que estão sempre exigindo atualização. A temporalidade resultante desse processo é, tecnicamente, de vinte e quatro horas, o equivalente a sua periodicidade. No tocante à circulação no meio social, não há muitas mudanças. Um jornal de periodicidade diária, por exemplo, suscita uma baixa temporalidade daquilo que aborda, porque a atualização do dia seguinte arrefece o impacto discursivo do que foi tratado nos dias anteriores. Acreditamos que isso aconteça ainda que se dê continuidade a um mesmo assunto, tratado em um mesmo gênero jornalístico e produzido por um mesmo autor, por mais de um dia, ou seja, quando o objeto do discurso é retomado por mais de uma edição do jornal. Apesar disso, há a possibilidade de que os temas menos circunscritos aos acontecimentos da atualidade e que não requeiram uma atualização incessante sejam menos efêmeros no contexto do dia a dia dos leitores.

As versões online dos jornais diários que mantêm o arquivamento virtual podem ter uma existência maior, pois a substituição do jornal por um uma nova publicação online não age em detrimento das publicações anteriores, se elas estiverem disponíveis para o acesso via internet. De qualquer modo, os objetos dos discursos e dos sentidos continuam determinantes, isto é, apesar de o acesso ser fácil e possível, o mais provável é que não haja interesse dos leitores por assuntos já tornados distantes, a não ser para fins de pesquisa. $\mathrm{O}$ arquivamento na internet permite a existência e a disponibilidade, mas não necessariamente uma circulação maior.

A versão online do ombudsman apresenta também outras especificidades. Por conta da sua periodicidade semanal, é provável que a circulação no meio virtual seja maior em relação à versão impressa do jornal de forma geral. Uma possível expectativa em relação à posição responsiva dos autores do ombudsman sobre os assuntos abordados no jornal durante a semana pode ser preenchida por diferentes leitores em diferentes dias da semana. Isso porque o jornal impresso logo se extingue, enquanto a versão online pode continuar sendo acessada ${ }^{14}$ após a data de publicação do ombudsman online. $\mathrm{O}$

\footnotetext{
${ }^{13}$ Da mesma forma que a subseção do ombudsman no Jornal da Manhã, essa subseção do ombudsman da Folha de S. Paulo não representa links. É somente uma listagem.

${ }^{14}$ Em relação à Folha de S. Paulo, essa constatação torna-se problemática, pois só os assinantes do jornal ou do provedor Uol têm acesso ao jornal.
} 
mesmo não ocorre com a maioria dos gêneros diários que compõem o jornal online em comparação ao ombudsman dessa mesma versão. Assim como no meio impresso, as atualizações diárias de muitos desses gêneros os tornam mais efêmeros em relação ao gênero ombudsman. No entanto, lembramos que somente o arquivamento virtual não oferece garantias de uma maior circulação desses outros gêneros, justamente porque a efemeridade e a atualização constante dos assuntos produzem a perda de interesse por parte dos leitores. Os seus exemplares mais atuais - a notícia, a manchete, a reportagem do dia - são mais interessantes do que aqueles dos dias anteriores. O ombudsman, por sua vez, publicado semanalmente, pode ter uma ressonância maior porque seus exemplares não são atualizados constantemente.

Outra característica do gênero ombudsman é que ele reaviva, ainda que por pouco tempo, assuntos de grande efemeridade tratados pelos jornais e pelos leitores. Ele traz à tona, novamente, temas e posições valorativas já abordados pelo jornal e pelos leitores, que avalia positiva ou negativamente. Por exemplo, O Jornal da Manhã tematizou, no dia 10 de dezembro de 2008, a questão da falta de atendimento a pacientes em uma unidade de saúde:

\section{Pacientes sofrem sem atendimento}

Falta de médicos, horas na fila de espera, tratamentos interrompidos e perda de dia de trabalho são algumas reclamações dos pacientes.

(Jornal da Manhã - 10 de dezembro de 2008)

A autora do ombudsman do jornal teve uma posição responsiva positiva sobre a reportagem na edição do dia 14 de dezembro de 2008:

Essa semana, quarta-feira, uma matéria surpreendeu justamente por colocar em prática a tão pedida pluralidade de vozes e participação da comunidade. Primeiro, porque não começa com aquele lead tradicional (o primeiro parágrafo da matéria que tem a função de responder às perguntas básicas da reportagem). Segundo, porque está recheado de personagens. Em 'Pacientes sofrem sem atendimento', da editoria Cotidiano, a participação da comunidade é vivaz. Seis pessoas foram ouvidas. Cinco eram da comunidade. Isso evidencia que o envolvimento do repórter na matéria, que foi até o local, conversou com a população. (Jornal da Manhã - Espaço da Ombudsman, 14 de dezembro de 2008)

No dia 10 de dezembro de 2008, no caderno Folha Ilustrada, do jornal Folha de $S$. Paulo, foi publicada uma nota sobre a aprovação da cota de meia-entrada:

\section{Com novas emendas, Senado aprova cota da meia-entrada.}

DA SUCURSAL DE BRASÍLIA

O projeto de lei que limita a meia-entrada em eventos culturais e esportivos foi aprovado ontem em segundo turno pela Comissão de Educação, Cultura e Esporte do Senado, com duas emendas que atendem reivindicações dos estudantes. A proposta segue agora à Câmara.

Foi mantida a cota de $40 \%$ dos ingressos para idosos e estudantes do ensino básico e superior. Mas uma emenda garante que as carteiras 
estudantis sejam expedidas apenas por algumas entidades, e outra regulamenta instrumento para controle da cota.

(LARISSA GUIMARÃES)

(Folha de S. Paulo - Folha Ilustrada de 10 de dezembro de 2008).

Em 11 de dezembro de 2008, no caderno Folha Dinheiro, do mesmo jornal, foi publicada uma reportagem sobre a ampliação do Supersimples. Expomos, aqui, um recorte do texto:

\section{Ampliação do Supersimples é aprovada \\ MARIA CLARA CABRAL \\ DA SUCURSAL DE BRASÍLIA}

Em votação unânime, a Câmara dos Deputados aprovou ontem projeto de lei que cria benefícios para micro e pequenos empresários. O texto, que já passou pelo Senado e segue para sanção do presidente Luiz Inácio Lula da Silva, amplia o número de categorias que poderão fazer opção pelo Supersimples, o regime especial de tributação do setor aprovado em 2006.

(Folha de S. Paulo - Folha Dinheiro de 11 de dezembro de 2008).

No ombudsman do dia 14 de dezembro ${ }^{15}$, o autor produziu a réplica que vem a seguir, destacando novamente os dois assuntos e criticando o jornal por não ter se antecipado aos acontecimentos ou não promover um debate sobre eles, ao invés de apenas noticiálos:

Por que esperar que a Câmara decida limitar a meia-entrada ou ampliar o Supersimples para só então noticiar? Por que não promover o debate entre os interessados nesses temas para que eles possam influir no resultado e se preparar para o que vier? (Folha de S. Paulo ombudsman de 14 de dezembro de 2008).

Como podemos observar nos dois trechos de dados apresentados, o gênero ombudsman retoma e reaviva os temas apresentados no jornal nos dias anteriores, tecendo uma teia de relações/movimentos dialógicos com os outros enunciados do jornal, conforme já mencionado nesta seção.

Já a abordagem do horizonte espacial remete à esfera de atividade que circunscreve o gênero. Os enunciados refratam em maior ou menor grau valorações e características discursivas de suas esferas ideológicas, entendidas como um lugar de enunciação. Para Bakhtin (1986 [1929], p.33), “Cada campo de criatividade ideológica tem seu próprio modo de orientação para a realidade e refrata a realidade à sua própria maneira. Cada campo dispõe de sua própria função no conjunto da vida social”.

A esfera do jornalismo é o lugar de enunciação do gênero ombudsman. Dentro desse espaço discursivo, há toda uma série de atividades que delineiam a organização, a estética, a valoração e a orientação ideológica do jornal, o que, consequentemente, concede aos gêneros que o compõem um acento apreciativo. Essas relações aparecem refratadas no lugar e posição dos gêneros no espaço de publicação do jornal impresso ou

\footnotetext{
${ }^{15}$ Exposta online somente no dia quinze de dezembro de 2008 por problemas de software, segundo aviso da Folha de S. Paulo.
} 
online. A localização do gênero ombudsman no jornal determina o seu valor (do gênero), sua maior ou menor credibilidade e importância. Para Rodrigues (2005, p.171):

O trabalho de seleção e divisão desse universo em cadernos, seções, rubricas e suplementos já é um ato temático, estilístico e composicional, pois esse ato de segmentação, além de selecionar e 'rotular' o que pode fazer parte de cada caderno, seção, é um índice de produção e interpretação indispensável dos enunciados individuais e dos gêneros.

No Jornal da Manhã online, o gênero ombudsman encontra-se vinculado, na página inicial do jornal, a uma seção maior denominada como Blogs e Colunas e é acessado em Blogs $^{16}$, tal como podemos observas na Figura 3:

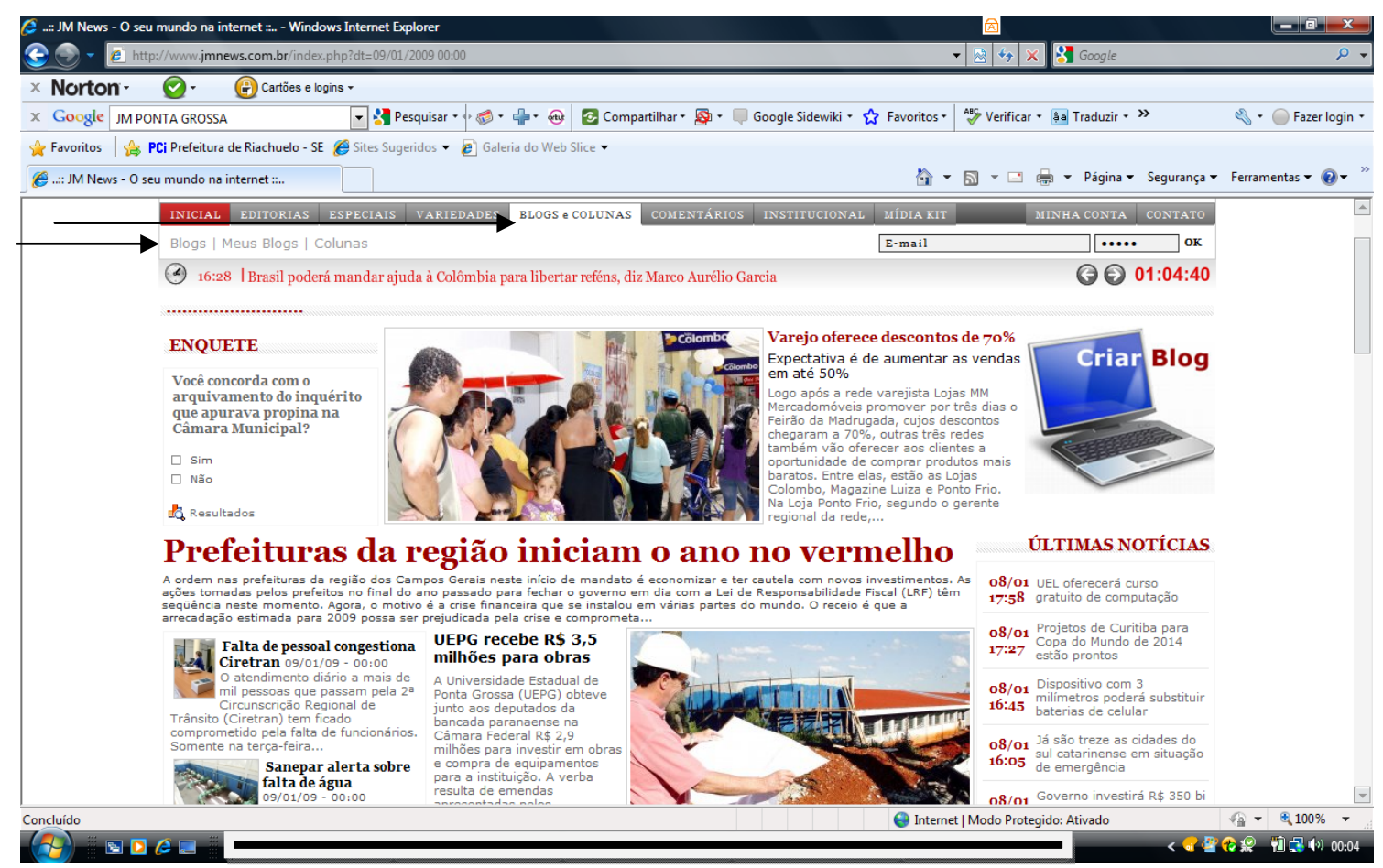

FIGURA 3. Página inicial do Jornal da Manhã de 09 de janeiro de 2009, com a indicação dos links que levam ao ombudsman ${ }^{17}$.

Fonte: http://www.jmnews.com.br/index.php?dt=09/01/2009 00:00

No que diz respeito à configuração dos gêneros no espaço do jornal, notamos essa dialogicidade entre o gênero ombudsman da versão online no Jornal da Manhã e o blog. O Espaço da Ombudsman no jornal da manhã recebe vários textos que correspondem à própria textualização do gênero. Os textos são postados pela autora e, como nos blogs,

\footnotetext{
${ }^{16}$ Além da versão online do jornal, em que o ombudsman encontra-se dentro da seção Blogs e Colunas, como já dito, o Jornal da Manhã mantém uma versão digital-fac-símile. Corresponde a uma reprodução idêntica ao jornal impresso. É similar ao resultado de um escaneamento. Na versão digital, a coluna do ombudsman aparece tal e qual na versão impressa. Por uma questão de uniformidade do objeto de pesquisa, decidimos manter a análise das versões ombudsman dos jornais online do Jornal da Manhã e da Folha de S. Paulo, já que o segundo não mantém a versão digital. Seria uma incoerência recorrer aos dados em versões diferentes.

${ }^{17} \mathrm{O}$ primeiro link de acesso é Blogs e Colunas. Após clicar nesse Link, os seguintes, embaixo, abrem-se: Blogs /Meus Blogs/ Colunas. O Ombudsman é acessado em Blogs.
} 
são acomodados em uma única página. A separação entre a edição de um determinado dia e de um outro ocorre por meio das datas em que foram publicados os ombudsman, juntamente com a inserção do título do primeiro texto, conforme se pode observar na Figura 4:

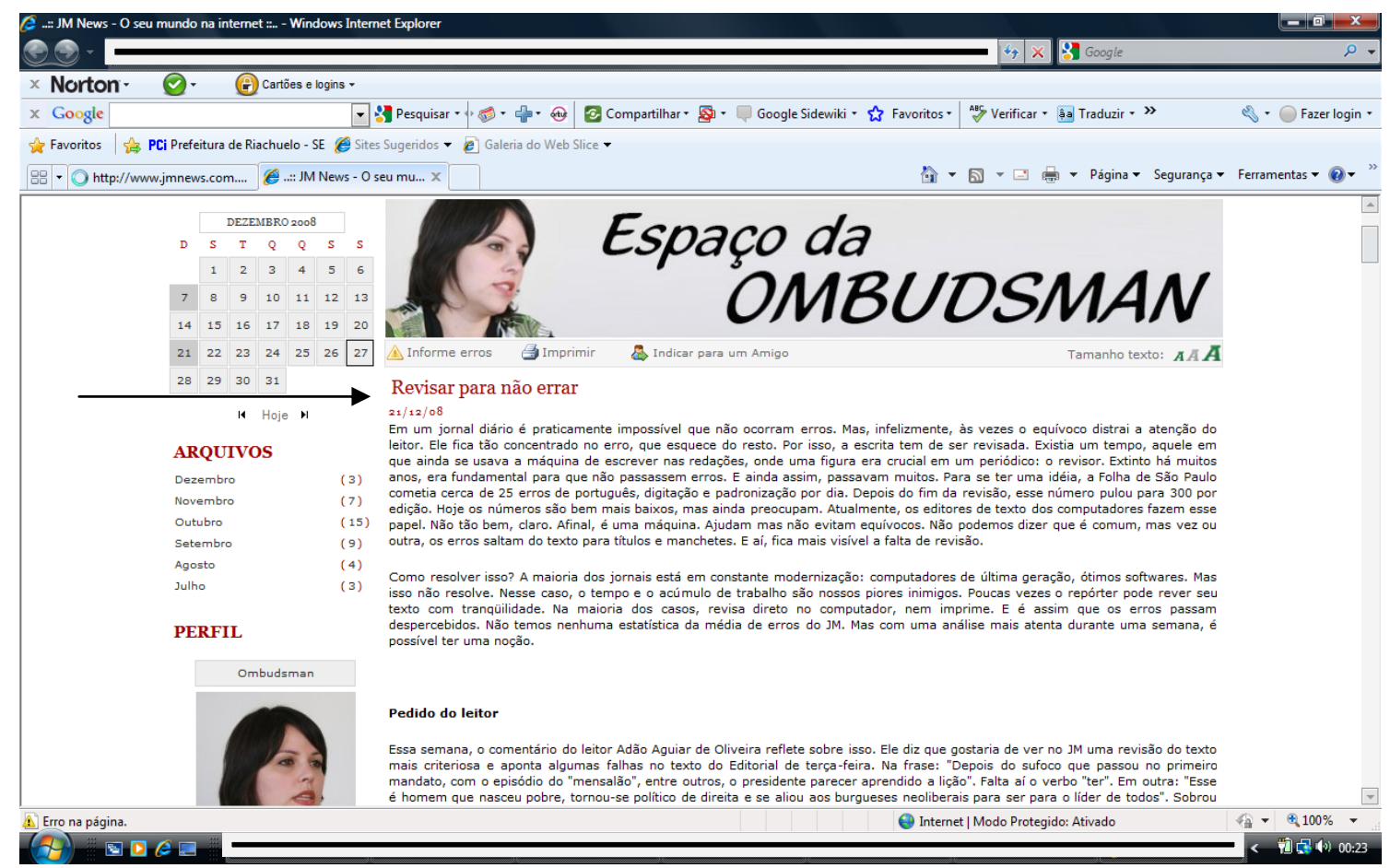

FIGURA 4. Inserção do título do primeiro texto do Espaço do Ombudsman, do Jornal da Manhã de 21 de dezembro de 2008.

Fonte: http://www.jmnews.com.br/index.php?SETOR=COLUNA\&CID=89\&POST=39282

O título em vermelho, junto com a data que segue logo abaixo, representa a edição da semana do ombudsman. O primeiro texto da edição do dia 30 de janeiro de 2008, imediatamente posterior à edição mostrada na figura acima, ocupou exatamente o lugar indicado na figura por uma seta. Nessa página, utilizando a barra de rolagem, o leitor encontra edições anteriores do ombudsman, identificadas também por um título em vermelho, e a data da publicação. Podemos visualizar isso na Figura 5. O título e a data marcam uma publicação anterior do ombudsman, que aparece na mesma página do texto da Figura 4 (Espaço da Ombudsman de 21 de dezembro de 2008) como um contínuo, similar aos blogs. As posições da barra de rolagem na Figura 4 e na Figura 5 indicam que houve movimento para baixo. 


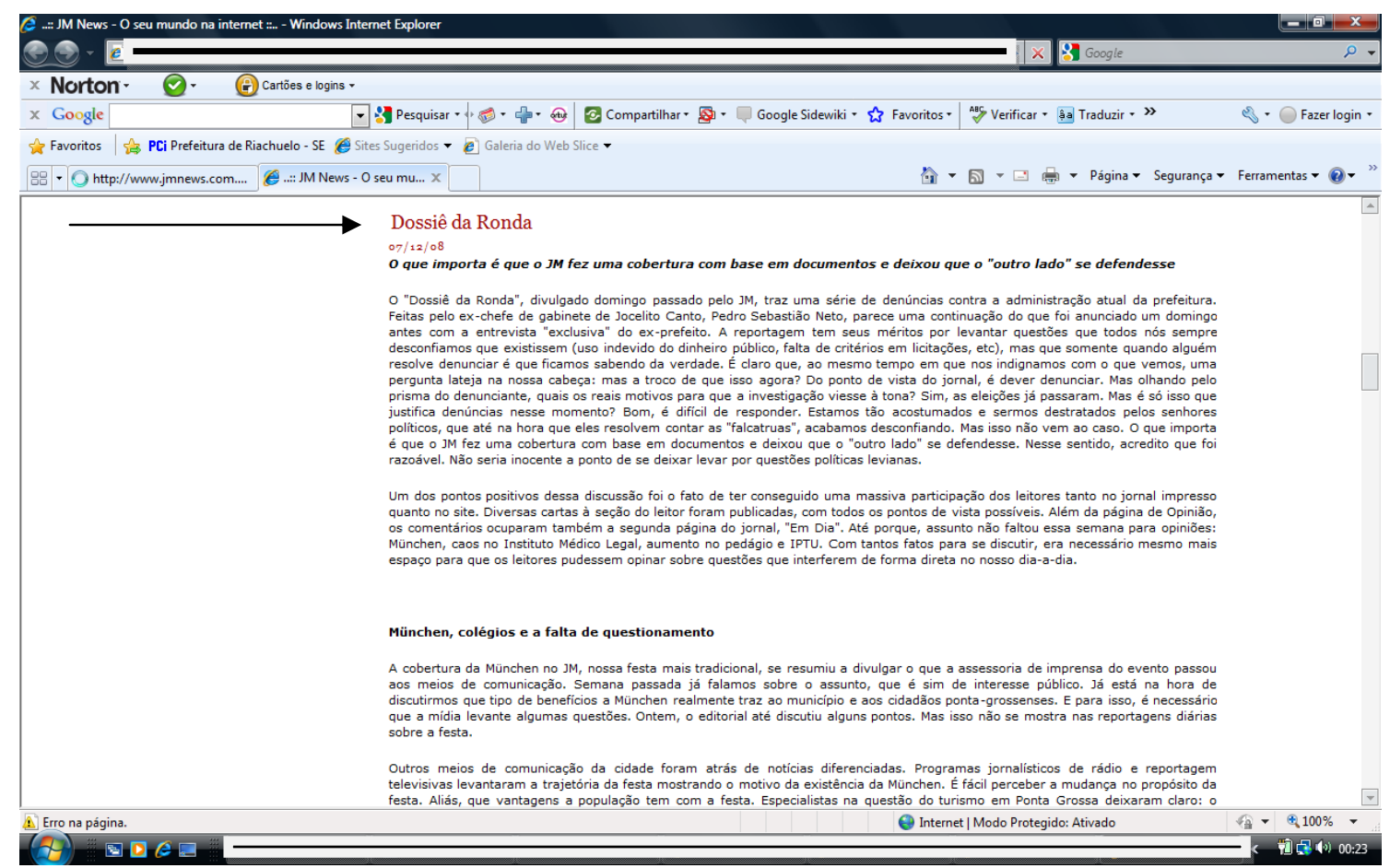

FIGURA 5. Jornal da Manhã - Espaço da Ombudsman de 07 de dezembro de 2008 na página contínua do ombudsman de 21 de dezembro de 2008.

Fonte: http://www.jmnews.com.br/index.php?SETOR=COLUNA\&CID=89\&POST=39282

Além do acesso no topo da página inicial do jornal, no link Blogs e Colunas, há outro link nessa página inicial, chamado Fale com a Ombudsman, que leva direto ao texto do ombudsman. Esse destaque na página de abertura do jornal demonstra a credibilidade que o gênero tem dentro do espaço do jornal, conforme podemos observar na Figura 6.

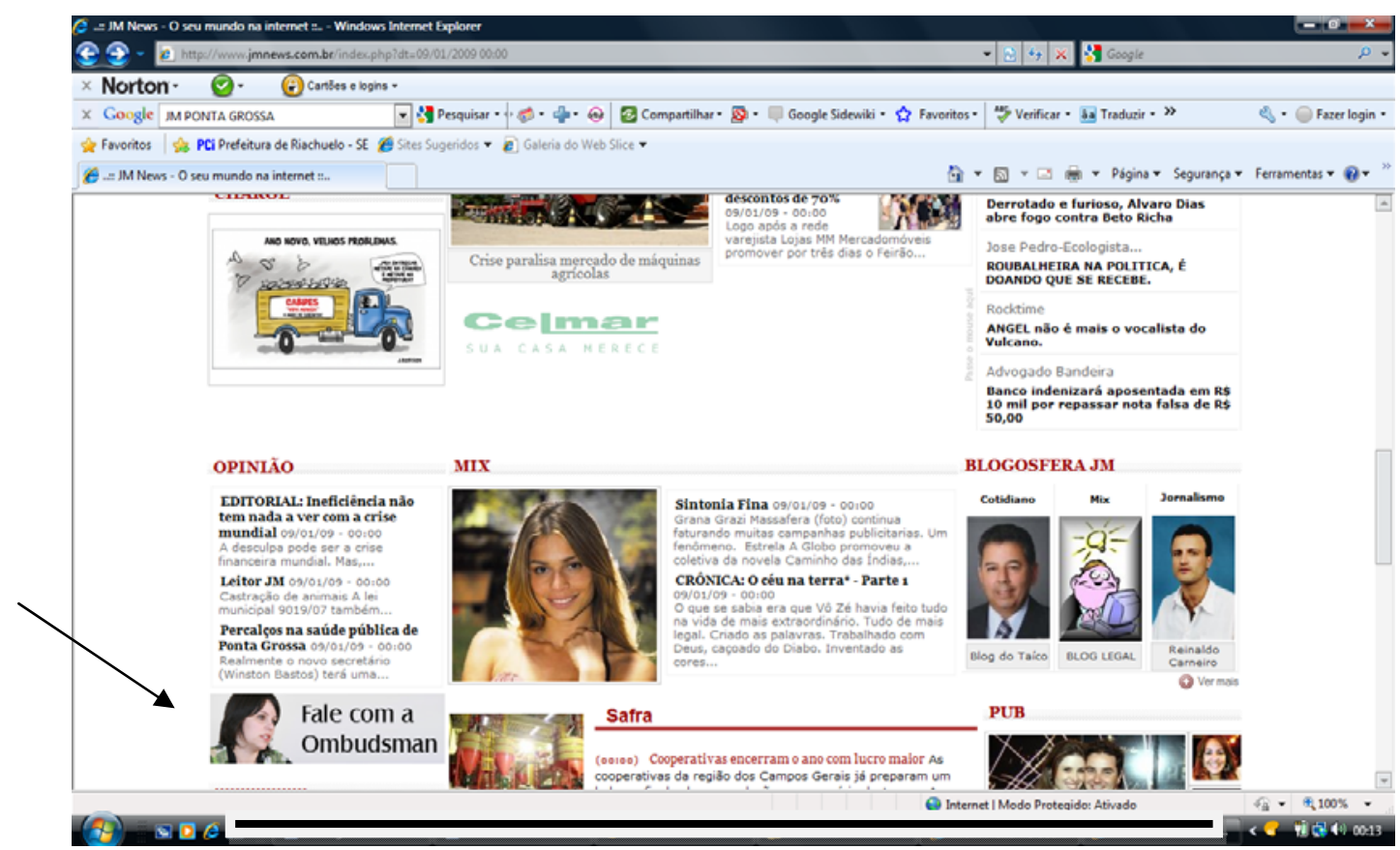

FIGURA 6. Espaço do Fale com a Ombudsman, do Jornal da Manhã - página inicial de 09 de janeiro de 2009

Fonte: http://www.jmnews.com.br/index.php?dt=09/01/2009 00:00 
Na Folha de S. Paulo, o gênero pode ser acessado na página inicial, em ServiçosOmbudsman. Esse link leva a uma espécie de página de apresentação do gênero, que não é ainda da autoria de Carlos Eduardo Lins da Silva, ombudsman da Folha. Nessa página, são encontrados links, que, quando acessados, dão informações sobre a profissão. Alguns desses links são: O que é o ombudsman; Dúvidas frequentes (sobre o ombudsman); Colunas anteriores. É interessante notar que na página de apresentação há um link para uma entrevista realizada pela Folha com o seu ombudsman. Na página de apresentação se encontra também o link Coluna de domingo, que leva ao gênero propriamente dito. O acesso é, no entanto, restrito aos assinantes da Uol ou da própria Folha.

Ao contrário do Jornal da Manhã, o ombudsman da Folha não tem seu texto publicado como um blog. São, geralmente, três textos para cada publicação semanal, ou seja, são postados no mesmo dia, mas acessados por links separados. A separação por links na versão online equivale à separação em subseções na versão impressa. Os textos podem ser primeiramente acessados no índice do ombudsman, como mostrado a seguir, na Figura 7: cada um dos links (destacados pela seta) leva a um texto diferente, mas que são postados no dia que está identificado acima dos títulos desses textos. Nesse exemplo, os textos apontados pertencem à edição do ombudsman do dia 21/12/2008.

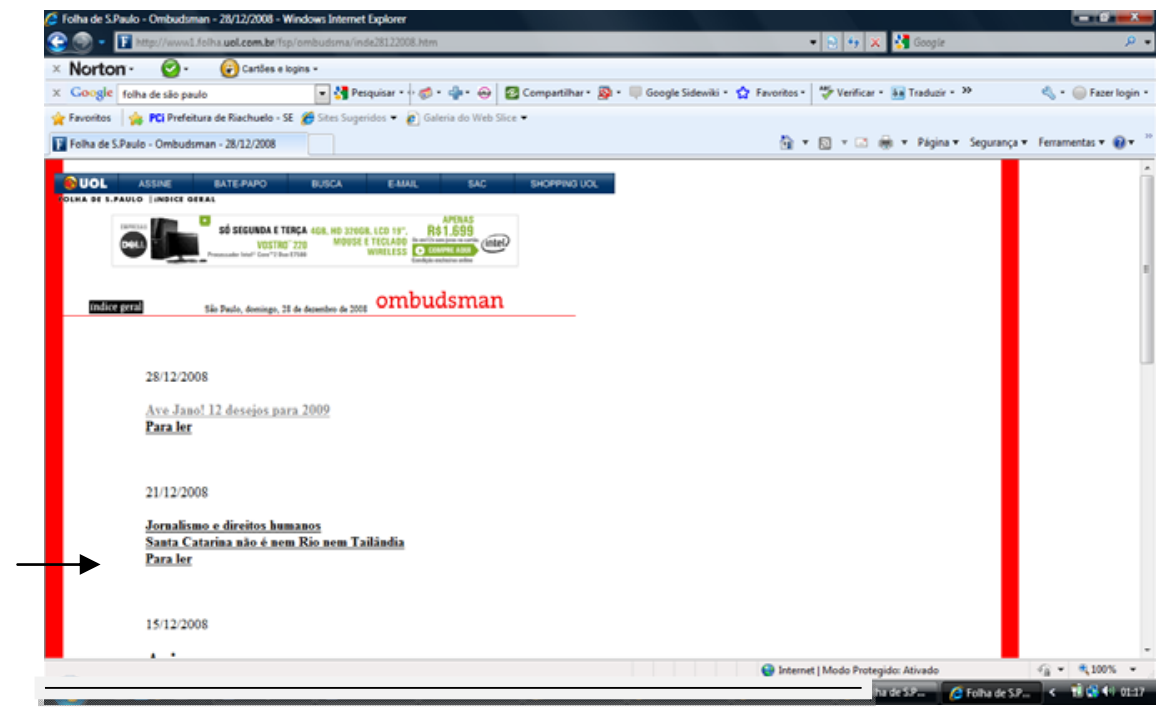

FIGURA 7. Índice do ombudsman da Folha de S. Paulo - ombudsman de 28 de dezembro de 2008.

Fonte: http://www1.folha.uol.com.br/fsp/ombudsma/inde28122008.htm

O leitor pode passar a outro texto do mesmo dia por meio de um link no texto que está sendo lido, como podemos observar na Figura 8. 


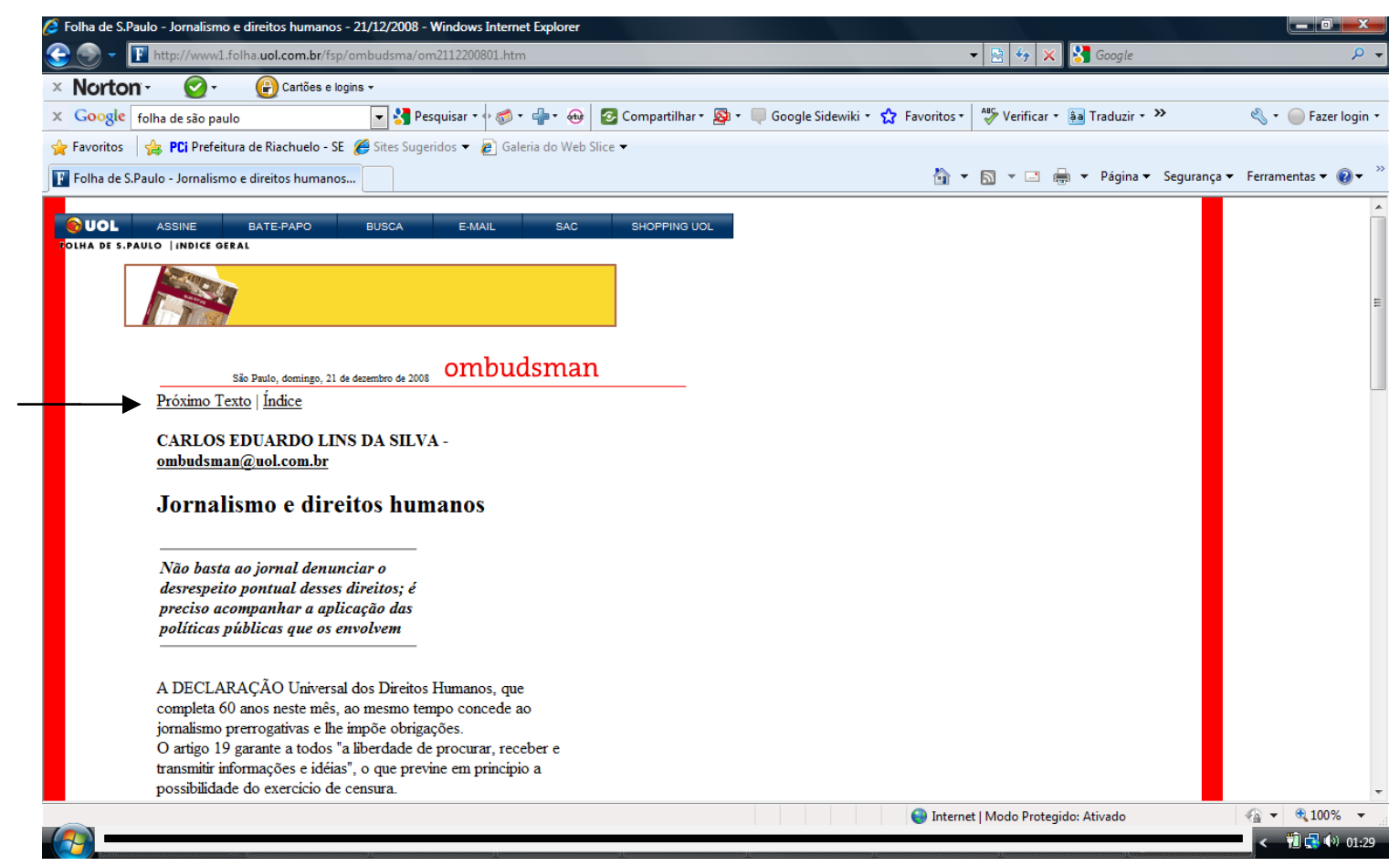

FIGURA 8. Seta - link que leva o leitor aos diferentes textos do ombudsman, do dia 21 de dezembro de 2008 - Folha de S. Paulo - ombudsman de 21 de dezembro de 2008

Fonte: http://www1.folha.uol.com.br/fsp/ombudsma/om2112200801.htm

Observando outro jornal que apresenta o gênero ombudsman, o jornal O Povo, da cidade de Fortaleza, notamos que os textos são apresentados por meio de um único link na página inicial do jornal. Essas diferentes organizações espaciais do gênero em sua versão online entre os jornais nos levam a afirmar que, ao menos no ambiente virtual, o gênero apresenta relativa padronização quanto ao modo como é ancorado e exposto nas diferentes seções do jornal. É, provavelmente, resultado das diversas possibilidades organizacionais oferecidas pela internet e, ainda, pela novidade que esse meio apresenta para a circulação do jornalismo.

\subsection{Os interlocutores/participantes da interação}

Feita a análise da dimensão espacial e temporal do ombudsman no jornal, iremos tratar de outros aspectos importantes para o delineamento da dimensão social do gênero, a começar pela questão da interação e de seus participantes.

Consideramos como participantes da interação do gênero o profissional ombudsman enquanto autor e os leitores que compõem o público-alvo do jornal. O autor do gênero retoma uma posição responsiva crítica diante do tratamento dado pelo jornal a seus conteúdos temáticos. Obviamente, mantém-se a dialogicidade entre o gênero e o jornal veículo que o comporta. Porém, as críticas feitas ao jornal são endereçadas ao leitor, são publicizadas. Mesmo porque grande parte do que o autor critica ou elogia em seu texto nasce a partir da apreensão que ele tem da posição do próprio leitor em relação ao que é abordado no jornal durante a semana. 
Nesse sentido, podemos dizer que o jornal como um todo se mantém mais como objeto do discurso e dos sentidos do ombudsman do que como interlocutor/participante imediato dessa interação. Junto com a posição responsiva ativa do leitor, o jornal é um dos temas do gênero ombudsman.

Em termos bakthinanos, podemos definir essa interação da seguinte forma: eu assumo uma posição crítica a respeito de um outro, mas minha crítica sobre esse outro não é dirigida diretamente a ele e sim a um terceiro, que corresponde ao leitor. Do contrário, não haveria a necessidade de publicação da crítica ou do elogio; logo, a publicação é para o leitor, que se constitui o outro imediato da interação. Ele pode ser o leitor geral que compõe o auditório social do gênero ou um leitor específico, como no caso em que o autor cita seu nome:

Também é crescente o número de comentários sobre erros nos conteúdos de algumas reportagens. Sábado passado, José Antônio Chaves Vaz Júnior escreveu sobre a reportagem 'Pai de família mata esposa e foge', de Cotidiano. Segundo ele, o fato ocorreu na Vila Bertha e não no Davi Federmann como constava na matéria. (Jornal da Manhã - Espaço da Ombudsman de 21 de dezembro de 2008).

Dois leitores se queixaram de fotos de crianças mortas. Zuleika Haddad perguntou: 'Por que a Folha precisa estampar foto de uma menina de 4 anos em seu funeral?'. Geraldo Pietragalla Filho argumentou que as fotos 'em nada contribuem para a compreensão dessa guerra insana; são manifestações mórbidas'. (Folha de S. Paulo - ombudsman de 04 de dezembro de 2009).

A versão online do Jornal da Manhã tem uma particularidade interessante. O jornal mantém o blog da redação que, entre outros assuntos, propicia aos jornalistas justificativas e comentários em relação às críticas recebidas do ombudsman. Reiteramos que há sempre dialogicidade entre os enunciados e seus gêneros que compõem o jornal, mas, no que concerne especificamente ao gênero ombudsman, mesmo com a réplica dos jornalistas e repórteres cujos textos foram tema do ombudsman, os participantes imediatos explícitos ${ }^{18}$ da interação ainda continuam sendo o ombudsman e os leitores. Em primeiro lugar, porque o ombudsman parece não abordar as justificativas dos jornalistas postadas no blog da redação, como em uma retomada/tréplica do que gerou sua crítica. Em segundo lugar, quando os jornalistas se justificam no blog da redação, o seu endereçamento imediato, assim como o do ombudsman, é para o leitor, pois o blog é endereçado, em primeiro plano, para ele. Esse evento corresponde a um eu que se justifica, mas não diante de um outro que o critica. Esse eu se justifica para um terceiro, o leitor.

De qualquer forma, os jornalistas também podem ser/são leitores do jornal em que atuam e, portanto, do texto do ombudsman. Nesse caso específico, eles assumem a

\footnotetext{
${ }^{18}$ Ressaltamos que se trata dos interlocutores imediatos previstos, pois, como bem mostram as réplicas, os jornalistas comentados no texto do ombudsman também dialogam com ele: no ato da leitura, passam de objeto do discurso a interlocutores. Como lembra Bakhtin (2003 [1971], sempre há os interlocutores não previstos para o enunciado, embora, no caso do ombudsman, poder-se-ia levantar também a hipótese de que os jornalistas e repórteres, junto com o jornal, são, também, interlocutores imediatos da interação. Eles assumiriam a função de interlocutores implícitos do gênero.
} 
posição de participantes da interação, pois ocupam outra posição interlocutiva, a de leitor do ombudsman, mesmo que a sua responsividade ativa seja diferente da posição responsiva ativa do auditório social do veículo. Já no exercício de sua função, os jornalistas estão em outro lugar de enunciação. É quando seus enunciados são orientados também aos leitores do jornal, suscitando a interação entre esses dois grupos de interlocutores.

Uma interação muito mais estreita entre o ombudsman e o jornal não se dá no plano do gênero em estudo. Isso ocorre a partir da crítica interna e do encaminhamento das queixas dos leitores ao jornal via ombudsman. Nesse ponto, estamos nos referindo ao ombudsman enquanto função profissional (cargo), interno à esfera do trabalho do jornal, ao invés do autor do gênero ou do gênero ombudsman propriamente dito, no âmbito da esfera jornalística. Na atividade jornalística, o ombudsman não consiste somente em um autor de um texto crítico. Sua atividade se estende à função de ouvidor. Na página de abertura do ombudsman da Folha de S. Paulo, há o link O que é o cargo? No texto, é explicado que:

O jornal assumiu o objetivo de ter seu próprio ombudsman, um profissional dedicado a receber, investigar e encaminhar as queixas dos leitores; realizar a crítica interna do jornal e, uma vez por semana, aos domingos, produzir uma coluna de comentários críticos sobre os meios de comunicação na qual a Folha deveria ser um dos alvos privilegiados. $^{19}$

O que se chama de crítica interna remete a uma interação constante e direta entre o ombudsman (cargo) e o jornal (empresa), no âmbito da esfera do trabalho. Essa crítica interna nem sempre é aquilo que se publica no jornal. Percebemos isso na entrevista feita pela própria Folha com seu ombudsman, Carlos Eduardo Lins da Silva, que, entre outros assuntos, discorre sobre o problema da crítica interna ser publicada ou não.

[...] porque o fato de ser restrita à Redação não vai impedir que a concorrência e grupos políticos tenham acesso a ela. É impossível impedir que algo que seja distribuído a mais de uma centena de jornalistas não vaze para fora do jornal. ${ }^{20}$

Além da crítica interna, fala-se no encaminhamento das queixas dos leitores. Do mesmo modo que a crítica, esse encaminhamento sugere uma interação de caráter interno entre o ombudsman (cargo) e o jornal (empresa).

No que se refere ao Jornal da Manhã, a crítica interna não é feita. Perguntamos sobre a o assunto a Elaine Javorski, ombudsman dessa publicação, por meio de uma entrevista realizada via e-mail:

Autores do artigo: O seu trabalho de ombudsman implica uma crítica interna ao jornal?

\footnotetext{
${ }^{19}$ Disponível em <http://www1.folha.uol.com.br/folha/ombudsman/cargo.shtml $>$. Acesso em: 14 de dezembro de 2008.

${ }^{20}$ Disponível em < $<$ http://www1.folha.uol.com.br/fsp/ombudsma/om2004200801.htm> Acesso em: 14 de dezembro de 2008.
} 
Elaine: Meu diálogo com o jornal é somente através da coluna. Não fazemos críticas diárias ou internas. Já houve um caso em que postei no blog algumas críticas durante a semana, mas é raro que isso aconteça.

Para saber mais sobre o procedimento da crítica interna, examinamos também o jornal O Povo e notamos que o jornal traz na página do ombudsman a seguinte informação:

Diariamente, o ombudsman faz uma crítica interna do material publicado no jornal, que também é debatida pela Redação, e atende os leitores. Escreve uma coluna semanal, publicada aos domingos.

Outro exemplo da interação de caráter interno nos é dado por Amaral (1993, p.133), ao informar que: “[...] o jornal Washington Post, um dos mais importantes dos Estados Unidos da América, introduziu seu ombudsman, para examinar queixas dos leitores e servir de crítico interno”.

A réplica imediata do leitor para com o ombudsman, em ambos os jornais dos dados analisados, materializa-se por meio de carta, fax ou e-mail. A Folha de S. Paulo ainda oferece a opção do telefone. Essa interação específica mostra que pode haver um contato prévio entre o leitor e o ombudsman. Uma informação da Folha de S. Paulo sobre as atribuições do cargo elucida a questão:

Suas atribuições são criticar o jornal sob a perspectiva dos leitores, recebendo e verificando suas reclamações, e comentar, aos domingos, o noticiário dos meios de comunicação. ${ }^{21}$

Essa é outra forma de interação que não se dá no plano do gênero. O ombudsman exerce uma função mais específica de ouvidoria para só depois efetuar a que se refere à autoria do ombudsman. Em síntese, delineamos três formas de interação suscitadas em torno do gênero ombudsman: a do gênero propriamente dito, ou seja, entre ombudsman (autor) e o leitor; entre o ombudsman (cargo de ouvidor) e o leitor, fora do plano do gênero estudado; entre o ombudsman (cargo de ouvidor) e o jornal enquanto empresa, também fora do plano desse gênero, embora em relação dialógica com ele, como no primeiro caso.

\section{4 $\mathrm{O}$ endereçamento e o fundo aperceptivo: o leitor previsto}

Na teoria dialógica da linguagem, todo enunciado prevê sempre uma réplica, por isso não há enunciado sem um endereçamento. Por conseguinte, não há enunciador apartado da antecipação de seu destinatário e seu fundo aperceptivo. O enunciador, ao produzir seu enunciado, ajusta-o ao gênero do discurso da interação, mas também à ideia que tem do conhecimento, dos saberes e do repertório cultural de seu destinatário.

A versão online do Jornal da Manhã disponibiliza o perfil do leitor ${ }^{22}$, que é produzido via pesquisa de mercado para ser direcionado aos potenciais anunciantes do jornal. Esse

\footnotetext{
${ }^{21}$ Enunciado presente nas edições online da coluna do ombudsman.

${ }^{22}$ Disponível em <http://www.jmnews.com.br/portal/objetos/midiakit/apresentacao/perfil_jm.pdf>.

Acesso em:14 de dezembro de 2008.
} 
perfil dá uma ideia do público que lê o Jornal da Manhã. É para esse público que o ombudsman tece suas posições. Entre outras informações, o perfil do leitor do Jornal da Manhã traz as seguintes caracterizações: $74 \%$ dos leitores fazem parte da classe A; $69 \%$ são graduados; $31 \%$ assumem cargos de gerência ou chefia; $62 \%$ são casados; $42 \%$ estão em uma faixa etária entre os 40 e 49 anos de idade.

Uma coluna da Folha de S. Paulo ${ }^{23}$ traz informações sobre o perfil do leitor do jornal. Alguns desses dados são os seguintes: a média de idade dos leitores é de 40,3 anos; têm alta escolaridade, pois 47\% fizeram faculdade e 13\%, pós-graduação; 53\% têm renda mensal individual de até 15 salários mínimos; 36 \% têm renda familiar acima de 30 salários mínimos; 52\% são casados. Segundo posição do jornal, entre os leitores da Folha predomina uma visão liberal, condição percebida através da apreensão de suas opiniões sobre aborto, pena de morte e uso de drogas, por exemplo. Em síntese, podemos dizer que os leitores dos dois jornais fazem parte de segmentos sociais privilegiados, têm uma vida financeira bastante estável, bom nível cultural e estão no topo da pirâmide social.

Em comparação à autoria dos outros gêneros que compõem o jornal e sua relação com seu interlocutor, o ombudsman tem uma vantagem: como exerce também uma função de ouvidor na sua relação com o jornal, ele pode ter um contato com os leitores, ao longo de seu mandato, que transcende as informações da pesquisa. Logicamente, o jornal como um todo necessita de uma boa noção de quem é o seu leitor. Os outros jornalistas não dispensariam isso, pois eles precisam apreender, até certo ponto, o fundo aperceptivo do destinatário. Nesse sentido, o próprio ombudsman pode ajudar, pois uma de suas funções no jornal é levar as críticas dos leitores à redação. Porém, o ombudsman é muito mais focado no conhecimento desse leitor porque ele não precisa escrever notícias, resenhas ou fazer reportagens, mas sim a sua coluna semanal, que prevê esse contato mais intenso com o público.

O Jornal da Manhã online parece privilegiar a posição responsiva ativa do leitor porque, ao fim das matérias publicadas no jornal, há um espaço para a postagem de seus comentários, que também são expostos separadamente em um link da página inicial, chamado Comentários do leitor. A Folha de S. Paulo traz em sua página inicial o link para o Painel do leitor, em que visualizamos também a opinião dos leitores sobre os assuntos tratados pelo jornal. No entanto, não há um espaço de postagem direta, como no Jornal da Manhã. O recebimento das opiniões se dá através de carta, fax ou e-mail. De qualquer modo, em ambos os jornais há essas outras possibilidades de interação entre os jornalistas e os leitores. Para o ombudsman, é provável que esses meios, acessíveis a todos os profissionais da empresa jornalística, somem-se às suas formas de contato exclusivo como mais uma fonte de conhecimento da posição responsiva do público de seu jornal.

Nos dados analisados, em ambos os veículos, o discurso do ombudsman enfoca com maior frequência a abordagem de enunciados de outros gêneros do jornal cuja temática é social e política ${ }^{24}$. São temas que exigem do leitor conhecimento específico, bom nível

\footnotetext{
${ }^{23}$ Disponível em < http://www1.folha.uol.com.br/folha/80anos/quem_e_o_leitor.shtml>. Acesso em: 21 de dezembro de 2008.

${ }^{24}$ Veremos isso com mais propriedade na análise do horizonte temático.
} 
cultural de leitura e uma boa compreensão. A não ser que o jornal trate esses temas de modo sensacionalista, tudo isso é dispensável, mas não é caso dos veículos aqui analisados. As escolhas dos autores do ombudsman demonstram que eles tomam os leitores como pessoas esclarecidas e que se interessam por esses temas. Os textos dos autores são claros e objetivos, porém não resvalam para um tom muito informal, para um discurso panfletário ou uma linguagem considerada de baixo nível. É o conhecimento do fundo aperceptivo do leitor que também orienta a essa linguagem e à temática do ombudsman. As reclamações dos leitores enquadradas pelos autores do ombudsman também revelam a reflexão sobre questões que exigem senso crítico, nível cultural ou conhecimento de mundo - sexismo no jornal (Folha de S. Paulo -Painel do leitor de 24 de dezembro de 2008) ${ }^{25}$, erros de português do jornal (Jornal da Manhã Comentários, 16 de dezembro de 2008) ${ }^{26}$, fotos publicadas em notícias e que chocam o leitor. Os autores do gênero parecem notar muito bem os traços comuns que compõem o fundo aperceptivo dos leitores. De acordo com esse conhecimento, eles conseguem regular seu discurso, seu tom, suas valorações e suas escolhas temáticas.

\subsection{A autoria}

Ao longo do tempo, as primeiras ideias sobre autor e autoria foram sendo novamente abordadas e desenvolvidas por Bakhtin e seu Círculo. Algo que preponderou foi a distinção entre autor-pessoa e autor-criador (BAKHTIN, 2003 [1979]). O momento da criação, por exemplo, difere do momento de reflexão sobre a obra criada. Quem reflete não é mais o autor-criador, mas sim o autor-pessoa, ser do acontecimento da vida cujas considerações sobre a própria criação não representam necessariamente uma verdade superior àquela alcançada por outros indivíduos diante da mesma obra. Não se reflete sobre o processo de criação no momento em que se cria. Nesse instante, a obra em desenvolvimento só pode ser vivenciada. $\mathrm{O}$ autor não se fixaria às determinações sociais e culturais da vida enquanto acontecimento. Elas são conformadas axiologicamente no acontecimento da criação, por isso, só se abrem às considerações do autor-pessoa no objeto criado depois de criado, como se abrem a um outro indivíduo qualquer em uma posição exotópica.

A dissociabilidade entre autor-pessoa e autor-criador veio a esgotar a ideia da onipotência de um autor individual e hermético. O autor-criador é uma posição de autoria, influenciada, entre outros elementos, pelas tipicidades do gênero que desenvolve. Ele então, sem apartar-se de sua responsabilidade, age também como um organizador do que lhe chega como dado, imprimindo-lhe a composição e o estilo. Nessa condição da autoria não reside uma só voz. É constituída pela heterogeneidade social, manifestada polifonicamente em maior ou menor grau a depender do gênero. A autoria implica uma posição responsiva ativa do autor-criador diante das vozes sociais com as quais lida e que, portanto, busca organizar.

Ao partirmos para a delimitação da autoria do gênero estudado, primeiramente nos atemos à representação que é concebida socialmente sobre o autor. Em ambos os jornais

\footnotetext{
${ }^{25}$ Disponível em <http://www1.folha.uol.com.br/fsp/opiniao/fz2412200810.htm>. Acesso em: 24 de dezembro de 2008.

${ }^{26}$ Disponível em <http://www.jmnews.com.br/index.php?setor=NOTICIAS\&nid=213331>. Acesso em: 16 de dezembro de 2008.
} 
- Jornal da Manhã e Folha de S. Paulo - os ombudsman são jornalistas experientes que atuaram em diversas áreas de sua atividade e possuem trajetórias contundentes dentro do universo mais amplo do que se convencionou chamar de comunicação, incluindo o campo acadêmico. Apesar de não fazer parte dos dados para a análise, também observamos o ombudsman do jornal O Povo. Concluímos que esse modo de representação da autoria se manteve uniforme.

As colunas que publicam o ombudsman trazem, além da assinatura e da foto do autor, informações sobre outras atividades desempenhadas por quem ocupa o cargo. Isso mostra que a indicação de autoria no gênero é bastante marcada. No caso da Folha de $S$. Paulo, essa marca de autoria intensifica-se ainda mais por trazer uma entrevista com o seu ombudsman na página de apresentação do gênero, como já foi comentado. Isso demonstra o interesse do próprio veículo jornalístico em delimitar claramente a autoria.

O delineamento da autoria a partir dos dados de pesquisa evidenciou a questão da polifonia envolvida. Como já dissemos antes, além da "espera” pelo que é abordado e pela posição valorativa a respeito do que é abordado no jornal, em seus vários gêneros, há também uma “espera” pela posição responsiva ativa do leitor, que é essencial para a composição da coluna do ombudsman. A partir da perspectiva sociodialógica de autoria, o ombudsman é um bom exemplo da orquestração de vozes realizada pelo autor-criador do gênero. Já mostramos que a Folha de S. Paulo evidencia que uma das atribuições do ombudsman (cargo dentro do jornal) é a crítica do jornal a partir da perspectiva dos leitores, manifestada no jornal na coluna dos domingos (ombudsman-autor). O Jornal da Manhã, em sua versão digital, mostra uma posição similar sobre a atividade:

Sua função é criticar o jornal com base no que dizem os leitores, ouvindo e verificando suas reclamações e sugestões. Os comentários são feitos aos domingos no jornal impresso e regularmente durante a semana no blog do ombudsman. ${ }^{27}$

As atribuições do cargo são efetivadas porque o ombudsman (profissional) ouve, verifica e lê as reclamações e sugestões dos leitores, e o que resulta dessa interação, ainda fora do gênero ombudsman, é, no momento da escritura/autoria, alocado, transportado para o plano da composição do gênero. Percebemos a transposição, o arranjo, pois a dialogicidade entre o autor-criador e as vozes dos leitores no gênero é muito contundente. Apesar de a autoria estar bastante marcada na representação feita pelos jornais, com base na perspectiva bakhtinana sobre autoria e autor, a posição responsiva ativa dos leitores, como discurso citado direta ou indiretamente em alguns dos textos analisados, sugere uma espécie de coautoria. Em muitos momentos de seu discurso, os autores tomam, por assim dizer, uma posição mais "solitária”, mas mostrou-se comum a clara inserção de outras vozes para a composição do seu discurso. Em algumas ocasiões, essa inserção suscita um tipo de crítica conjunta entre os autores e os leitores. O discurso de um leitor específico é um já-dito incorporado pelo autor do gênero. Segundo os estudos de Rodrigues (2005) sobre o gênero artigo assinado, da esfera jornalística, um dos elementos da dialogicidade entre o autor e o já-dito é o movimento dialógico de assimilação de vozes, logo, de orientações axiológicas. O autor

\footnotetext{
${ }^{27}$ Disponível em <http://www.jmnews.com.br/index.php?setor=JMDIGITAL\&cdid=1>. Acesso em: 14 de dezembro de 2008.
} 
incorpora outras vozes sociais para fortalecer o seu posicionamento. No tocante a esse movimento dialógico, verificamos que ocorre algo semelhante no gênero ombudsman, com a peculiaridade de se ter nesse gênero a voz do leitor como principal incorporação. A seguir alguns exemplos:

O leitor Wilson Marques me questionou por não ter incluído na coluna anterior opiniões de leitores sobre a cinquentona Ilustrada. Respondilhe que nestes sete meses como ombudsman praticamente não recebi cartas sobre o suplemento cultural da Folha.

Wilson questionou se o silêncio se deve à satisfação com o produto ou à apatia em relação a ele. Não tenho como responder com segurança, mas suspeito que seja mais por apatia do que por satisfação. (Folha de S. Paulo - ombudsman, 14 de dezembro de 2008).

A partir da questão levantada pelo leitor e do diálogo ocorrido e reportado, o autor começa a tomar sua posição, que, embora vacilante no início, ao longo do texto vai se consolidando até culminar com o seguinte posicionamento sobre o caderno Folha Ilustrada:

Minha impressão é a de que o caderno vem se tornando um guia de consumo e encara a cultura como simples mercadoria. Por isso, não suscita controvérsia, não anima polêmica, não ajuda a pensar. (Folha de S. Paulo - ombudsman, 14 de dezembro de 2008).

A posição responsiva ativa do autor dá continuidade ao questionamento crítico do leitor. Todo o texto que se segue é tecido a partir desse primeiro questionamento inserido no início, como se o leitor houvesse apontado o assunto do ombudsman a ser abordado.

Segue outro exemplo, observado no Jornal da Manhã. Em 16 de dezembro de 2008, um leitor, na seção Comentários, posicionou-se responsiva e ativamente sobre erros de português cometidos pelo jornal:

\section{[Adão Aguiar de Oliveira ]}

Meu comentário seria para que houvesse uma revisão do texto mais criteriosa. No seguinte parágrafo parece me faltar um verbo: 'Depois do sufoco que passou no primeiro mandato, com o episódio do 'mensalão', entre outros, o presidente parecer (ter) aprendido a lição.' e neste outro: 'Esse é homem que nasceu pobre, tornou-se político de direita e se aliou aos burgueses neoliberais para ser PARA o líder de todos. ' (Jornal da Manhã - Comentários - 16 de dezembro de 2008)

Em 21 de dezembro de 2008, encontramos no ombudsman o já-dito incorporado pelo autor:

\section{Pedido do leitor}

Essa semana, o comentário do leitor Adão Aguiar de Oliveira reflete sobre isso. Ele diz que gostaria de ver no JM uma revisão do texto mais criteriosa e aponta algumas falhas no texto do Editorial de terçafeira. Na frase: 'Depois do sufoco que passou no primeiro mandato, com o episódio do 'mensalão', entre outros, o presidente parecer aprendido a lição'. Falta aí o verbo 'ter'. (Jornal da Manhã - Espaço da Ombudsman de 21 de dezembro de 2008) 
Ainda nesse mesmo texto, vemos a posição responsiva ativa do ombudsman:

Em um jornal diário é praticamente impossível que não ocorram erros. Mas, infelizmente, às vezes o equívoco distrai a atenção do leitor. Ele fica tão concentrado no erro, que esquece do resto. Por isso, a escrita tem de ser revisada. (Jornal da Manhã - Espaço da Ombudsman de 21 de dezembro de 2008).

No exemplo, podemos observar o jogo de posições axiológicas do ombudsman para com o jornal e para com o leitor que criticou o jornal. Embora o autor, inicialmente, tome uma posição responsiva positiva para com o jornal ("Em um jornal diário é praticamente impossível que não ocorram erros”), o seu discurso é sutil em relação ao leitor ("Mas, infelizmente, às vezes o equívoco distrai a atenção do leitor"). Ainda que defenda o jornal, como nesse caso, o autor do gênero ombudsman orienta o seu enunciado a uma negociação com o leitor. Ele sugere um reconhecimento da posição tomada, a defesa do jornal, sem que isso represente o descrédito da opinião do leitor (embora sua crítica seja minimizada (deve-se dar mais atenção que aos conteúdos)). Isto é, não obstante a defesa, o discurso do leitor deve receber resposta do ombudsman.

Em relação aos leitores, o gênero ombudsman encontra-se em uma posição central. O discurso do leitor pode surgir como um já-dito que é incorporado pelo gênero, pois é anterior ao discurso do gênero na coluna publicada semanalmente. Ao mesmo tempo, o ombudsman dirige-se aos outros leitores previstos, entre os quais esse mesmo leitor determinado, específico, cujo discurso foi incorporado no texto pelo autor. Conhecer os seus leitores leva o autor a "prever" sua posição responsiva ativa. Isso nos remete a mais um movimento dialógico identificado no gênero artigo assinado por Rodrigues (2005), e que mais uma vez parece se aplicar bem ao gênero ombudsman, com suas devidas especificidades. Trata-se do movimento dialógico de engajamento. $\mathrm{O}$ efeito de coautoria entre o ombudsman e o leitor citado e enquadrado, quando o primeiro responde positivamente à posição do segundo, fortalece uma expectativa de defesa do leitor geral. Como uma das funções do ombudsman é a crítica ao jornal segundo o posicionamento dos leitores, seu engajamento dialógico já lhe asseguraria certa previsibilidade de uma visão positiva sobre seu discurso.

Observamos outras formas de orquestração das vozes. Na publicação do ombudsman da Folha de S. Paulo do dia 04 de janeiro de 2009, o autor discorda de dois leitores a respeito da publicação de fotos de impacto no jornal:

Dois leitores se queixaram de fotos de crianças mortas. Zuleika Haddad perguntou: 'Por que a Folha precisa estampar foto de uma menina de 4 anos em seu funeral?'. Geraldo Pietragalla Filho argumentou que as fotos 'em nada contribuem para a compreensão dessa guerra insana; são manifestações mórbidas'.

A morbidez deve ser evitada a todo custo, e o jornal precisa tomar muito cuidado com isso. Não acho que tenha esbarrado nela por enquanto.

Imagens fotográficas chocantes podem servir a propósitos humanitários e ajudar a manter vivos na memória coletiva horrores inomináveis e, com isso, dificultar a ocorrência de similares. (Folha de S. Paulo - ombudsman de 04 de janeiro de 2009). 
Em outra ocasião, como na publicação do ombudsman do Jornal da Manhã do dia 30 de dezembro de 2008, o autor enquadra duas vozes discordantes entre si sobre cujas apreciações ele não se posiciona. Sua opinião é direcionada à editoria do jornal:

Uma editoria que trouxe assunto novo foi o Bola: o secretário de Esportes da próxima gestão do atual prefeito. Nesse caso também poderia haver depoimentos dos mais interessados: os profissionais do esporte. Comentários do site falam sobre o assunto, numa forma de complementá-lo. Exemplo é o que diz o leitor Ben Hur Chiconato: 'Imaginem vocês qual seria a reação dos médicos, por exemplo, se, para assumir a pasta da saúde, fosse indicado um engenheiro. Dos advogados, se para assumir o setor jurídico fosse indicado um médico, ou dos engenheiros, para assumir o departamento de obras fosse indicado um assistente social. A indicação do prefeito foi sim, um murro na cara dos profissionais de educação física. São dois cursos de licenciatura e outros dois de bacharelado existentes na cidade. Dezenas de pessoas experientes e capacitadas para o cargo. $\mathrm{O}$ ato merece sim, manifesto da comunidade de profissionais da área'. Houve também comentários favoráveis, como do leitor João Almir Palhano, que escreveu: 'Parabéns pela escolha do Secretário de Esportes, apesar de não ser da área de esportes, trata-se de pessoa capacitada e muito competente para o Cargo, continua com Diretores experientes, isso demonstra humildade e responsabilidade com 0 esporte de nossa cidade'. A opinião da sociedade e dos profissionais da área completaria a reportagem. (Jornal da Manhã - Espaço da Ombudsman de 30 de dezembro de 2008).

O que há em comum nesses exemplos apresentados é o acento valorativo dado às vozes dos leitores. Não importa se há discordância ou não, efeito de imparcialidade ou não, o tom do autor sobre a posição responsiva ativa do leitor não chega a um extremo negativo, nem agressivo. Ao contrário, o acento valorativo refrata sempre uma espécie de respeito pelas opiniões. Na coluna do ombudsman da Folha de S. Paulo, o autor, inicialmente, não discorda dos leitores que não gostaram de ver fotos de crianças mortas no jornal. Em princípio, estabelece uma "concordância” com os eles. Nesse momento de aparente concordância, a modalização do seu enunciado é categórica, algo evidente no uso do verbo modalizador dever e da expressão "a todo custo", além da recomendação de cuidado: "A morbidez deve ser evitada a todo custo, e o jornal precisa tomar muito cuidado com isso”. No entanto, quando revela sua discordância em relação aos leitores, a modalização é arrefecida provavelmente para não provocar conflitos: “A morbidez deve ser evitada a todo custo, e o jornal precisa tomar muito cuidado com isso. Não acho que tenha esbarrado nela por enquanto". No lugar de "tenho certeza" ou "estou certo de que", o autor usa o verbo "achar" e ainda indica que existe a possibilidade de o jornal errar, quando usa o termo "por enquanto": "Não acho que tenha esbarrado nela por enquanto". Só depois da argumentação introdutória o autor realiza uma defesa mais sólida do jornal, o que demonstra uma espécie de negociação com os leitores para essa defesa.

O autor-criador exerce algum poder, já que é ele quem conforma as vozes à composição do gênero e do seu enunciado e sua condição jamais lhe isenta de um posicionamento axiológico. Se o gênero ombudsman abre-se para a justaposição de vozes, ao autor- 
criador cabe algum critério de seleção sobre quais vozes de leitores devem ser inseridas e não apenas como devem ser inseridas. Uma escolha ou outra deve ser feita. Parecenos que o resultado desse procedimento não deve deixar transparecer demasiadamente a organização das vozes sociais pelo autor, aquilo que entra ou não no seu texto. Do contrário, um sentido de autoritarismo ou censura poderia ser produzido, algo nada favorável a um discurso que sempre, ou quase sempre, orienta para uma relação harmônica ou de negociação com o discurso dos leitores e promove a defesa da face do jornal. Devido às atribuições do ombudsman, um efeito de sentido que se busca produzir é o da autonomia do autor em relação ao jornal enquanto empresa. Se existe uma liberdade da autoria referente ao posicionamento e à seleção e organização de vozes sociais, cabe-nos observar até que ponto a empresa jornalística determina ou não limites para esse exercício. Veremos isso com mais propriedade na análise do projeto discursivo.

\subsection{O horizonte temático}

Nesta seção apresentamos os objetos do discurso e dos sentidos do gênero nos dados analisados. Além de indicar quais são esses objetos, é preciso relacioná-los aos outros enunciados que estabelecem dialogicidade com o ombudsman, mesmo porque o que eles refletem e refratam serve de matéria prima ao próprio gênero.

Os jornais trazem uma série de conteúdos diferentes, abordados em diversos cadernos e gêneros jornalísticos. Esses assuntos diversos parecem, numa primeira leitura, ser o alvo dos comentários do ombudsman-autor, mas os seus grandes objetos apreendidos são o próprio jornal ou o jornalismo de modo genérico. O ombudsman aborda um assunto publicado no jornal, que pode ser de cunho político, social, cultural, esportivo, entre outros. O seu posicionamento suscita juízos de valor sobre o assunto propriamente dito, porém o que prepondera nos dados analisados é a visão do ombudsman, ou seja, seu horizonte apreciativo, sobre o modo como o jornal faz a abordagem desses assuntos e a atuação do jornalismo de uma forma geral. A autora da coluna do ombudsman do Jornal da Manhã mostrou-se criticamente mais minuciosa no que concerne ao jornal enquanto tema. O autor da coluna da Folha de S. Paulo mostrou-se mais insistente na crítica ao jornalismo como um todo. Assim, os resultados de análise mostram que o jornal e a atividade jornalística se apresentam como o objeto do discurso e do sentido do gênero em análise.

A posição responsiva ativa dos autores do gênero ombudsman sobre o jornal como objeto do discurso se configura nos dados analisados de dois modos: em sentido mais amplo, quando se referem aos jornais, por vezes, pelos nomes - Jornal da Manhã e Folha de S. Paulo; em sentido mais restrito, quando se referem a esse ou aquele caderno, editoria, matéria, ou um enunciado de um dado gênero, como um editorial ou uma reportagem. Como já vimos, críticas, comentários e sugestões dos leitores têm como objeto os próprios jornais, pois tem como ponto de partida os assuntos abordados pelo jornal. Portanto, quando os autores do ombudsman comentam esses tópicos, especificando ou não os leitores que os suscitaram, seu objeto do discurso permanece sendo o jornal. O que parte do leitor chega ao ombudsman como uma espécie de recorte valorativo sobre algo publicado pelo jornal, de que ele se utiliza para formar uma 
posição sobre o veículo, ou sobre a atividade jornalística, se não concordante com o leitor, ao menos em tom respeitoso.

Embora de menor ocorrência, outra característica é que outros elementos dos jornais, além de sua abordagem e conteúdo, podem ser criticados tanto pelo ombudsman quanto pelos leitores. Exemplo disso é a questão dos erros de ortografia e informações também erradas ou incompletas publicadas por parte dos jornais. O ombudsman do Jornal da Manhã de 21 de dezembro de 2008 é praticamente todo dedicado ao assunto. A Folha de S. Paulo faz o mesmo algumas vezes. De igual modo, podem ser avaliadas e criticadas as disposições e inserções de imagens, a repetição de notícias ou aspectos da composição linguístico-textual do veículo como um todo. A seguir, alguns exemplos de conteúdo temático do ombudsman:

a) A atividade jornalística como objeto do discurso:

O dever do jornalista também é cobrar e verificar se no dia seguinte o problema foi resolvido ou a fonte oficial só falou aquilo para se livrar do jornalista. Acredito que aí está a verdadeira função: mais do que denunciar, é necessário verificar a solução dos problemas. Caso contrário, a população continuará com as mazelas de sempre e, pior, sem acreditar que alguém possa ter força para mudar aquilo que está mal. (Jornal da Manhã - Espaço da Ombudsman, 14 de dezembro de 2008).

O JORNALISMO é uma atividade que sempre viveu de contar ao público os fatos do passado recente. O grande dilema de suas versões impressas é como permanecer necessário se nada mais é novidade quando elas chegam ao leitor.

A saída mais segura e óbvia é o veículo impresso se empenhar na explicação das razões por que as coisas aconteceram e mostrar quais serão suas possíveis consequências. (Folha de S. Paulo - ombudsman, 14 de dezembro de 2008).

b) O jornal (empresa) como objeto do discurso:

O JM tem buscado fazer um Jornalismo Público, dentro do conceito onde a comunidade participa ativamente na geração de pautas e assuntos que serão tratados. Mas, muitas vezes, é exatamente isso que sentimos falta: a voz dos cidadãos. É perceptível o interesse cada vez maior dos repórteres em trazer esses depoimentos para suas matérias. E esse é o caminho para um jornalismo de qualidade, interessado nos problemas da população. Ainda há muito o que avançar. É preciso rever e distinguir o que é jornalismo e o que é publicidade. Textos de assessorias de imprensa fazem com que os dois jornais da cidade se pareçam demasiado. (Jornal da Manhã - Espaço da Ombudsman, 30 de dezembro de 2008).

O presidente do Supremo Tribunal Federal, Gilmar Mendes, apareceu nas páginas da Folha 651 vezes durante o ano passado. O da Suprema Corte dos EUA, John Roberts, esteve nas do 'New York Times' no mesmo período 742 vezes. A diferença não é expressiva. (Folha de $S$. Paulo - ombudsman, 04 de janeiro de 2009). 
Mendes é diferente, em especial neste jornal, que lhe confere status de celebridade, nos seus piores aspectos. Em 50 textos em 2008, ele aparece fazendo declarações, muitas de cunho político, algumas repetidas duas vezes com títulos semelhantes ('o habeas corpus é como o ar') no espaço de quatro dias (12 e 16 de dezembro) (Folha de S. Paulo - ombudsman, 04 de janeiro de 2009). ${ }^{28}$

c) O próprio jornal como objeto do discurso a partir de suas divisões internas:

Na reportagem de domingo, em Política, 'Denúncias e cassações marcam ano da Câmara', uma informação ficou um pouco confusa. Primeiro, fala-se em CEI (Comissão Especial de Investigação) da Sanepar. Logo, na mesma matéria, aparece como CPI (Comissões Parlamentares de Inquérito) da Sanepar. (Jornal da Manhã - Espaço da Ombudsman, 30 de dezembro de 2008).

\section{ONDE A FOLHA FOI BEM...}

\section{Cartier-Bresson}

Excelente a idéia do caderno Mais! de domingo de pedir a grandes fotógrafos para recriar obras-primas de Cartier-Bresson.

\section{Sem manchete}

Edição de sexta acerta ao sair sem manchete de primeira página: se não há tema muito importante, é melhor isso que inflar nada desimportante

\section{...E ONDE FOI MAL}

\section{Sexismo}

Título de texto-legenda para foto de Carla Bruni e Camila Pitanga na capa de terça faz brincadeira sexista, antiquada e sem graça com os atributos físicos das personagens (Folha de S. Paulo-ombudsman, 28 de dezembro de 2008).

d) O jornal como objeto do discurso do leitor comentado pelo ombudsman:

O leitor Marlon Salomon irritou-se, justificadamente, com esta coluna, que errou no domingo passado, quando a legenda da foto disse que Joinville fica no vale do Itajaí.

A falha o levou a refletir sobre como jornalistas, em geral, em vez de se aprofundar num problema singular, preferem sacar fórmulas genéricas prontas, 'que valeriam tanto para SC quanto para RJ ou para um desastre na Tailândia!'. ${ }^{29}$ (Folha de S. Paulo - ombudsman, 21 de dezembro de 2008).

Também é crescente o número de comentários sobre erros nos conteúdos de algumas reportagens. Sábado passado, José Antônio Chaves Vaz Júnior escreveu sobre a reportagem 'Pai de família mata esposa e foge', de Cotidiano. Segundo ele, o fato ocorreu na Vila Bertha e não no Davi Federmann como constava na matéria. Na terça-

\footnotetext{
${ }^{28}$ A princípio, o texto do autor da coluna do ombudsman da Folha parece fazer uma crítica somente ao presidente do STF, Gilmar Mendes. No entanto, o direcionamento crítico é, na verdade, orientado ao jornal como um todo, à visibilidade que ele concede a Gilmar Mendes.

${ }^{29}$ Esse exemplo é interessante, pois o que leitor critica do jornal é a própria coluna do ombudsman. A coluna também compõe o veículo e, como tal, não está livre de julgamentos, por mais que se posicione em defesa do leitor.
} 
feira, a mesma editoria traz o título 'Bingo em igreja termina em morte na Vila Liane'. Celso Costa comentou que esteve na festa e o acontecimento foi no sábado à tarde e não no domingo, como dizia a reportagem. (Jornal da Manhã - Espaço da Ombudsman, 21 de dezembro de 2008)

Nos dados analisados, somente em uma ocasião o autor do ombudsman se concentra muito mais no conteúdo abordado em um dos enunciados do jornal do que no modo como o veículo aborda esse mesmo conteúdo. A autora da coluna do ombudsman do Jornal da Manhã faz comentários sobre uma entrevista com o prefeito da cidade de Ponta Grossa e, posteriormente, concentra-se em uma crítica direta à própria prefeitura e aos problemas da cidade:

Hoje, além do calçamento estar se soltando - o que mostra como é trabalhar com pressa - existe um verdadeiro caos nas ruas que cortam a avenida. Sim, dizem que depois que se completar as obras principais serão arrumadas as ruas secundárias. Mas e quando isso vai acontecer se as obras já deveriam estar prontas? Dinheiro público que hoje se despedaça e forma buracos nas calçadas. Mais uma vez o bolso do povo terá que pagar os reparos. O mesmo povo (principalmente pessoas idosas, cadeirantes) que sofre para conseguir praticar um direito básico: ir e vir. (Jornal da Manhã - Espaço da Ombudsman, 09 de janeiro de 2009).

O trecho acima se trata de uma exceção nos dados analisados. Reiteramos que a predominância temática do gênero envolve, primordialmente, o jornal que o acomoda, por vezes referido de forma genérica pelo nome do veículo ou especificamente quando se aborda os enunciados de seus gêneros jornalísticos - editoriais, reportagens entre outros. O gênero ombudsman tematiza também a composição do veículo. Encontramos exemplos referentes à escolha das imagens e o modo como são inseridas, à ortografia, à redundância de informações. Outro tema é a esfera discursiva do jornalismo como um todo, sua função e seu papel social.

\subsection{As relações dialógicas}

No que diz respeito somente ao plano discursivo interno do jornal enquanto atividade jornalística e do gênero ombudsman, as relações dialógicas nos dados analisados se apresentam basicamente como uma tríade entre jornal, leitor e autor do gênero. Já dissemos que fora do plano do gênero em estudo, há uma interação mais estreita entre o leitor, o ombudsman enquanto profissional de ouvidoria e o jornal enquanto empresa. Algo dessas relações dialógicas pode ou não se refletir no plano discursivo que envolve o jornal como atividade jornalística e o gênero ombudsman.

Assim sendo, no gênero ombudsman é possível observar uma tríade dialógica entre o autor, o leitor e o jornal. No plano discursivo interno dos jornais analisados, foi possível perceber a dialogicidade entre as três vozes em uma intercalação de enunciados de três gêneros diferentes. $\mathrm{O}$ ambiente virtual acomoda a intercalação de enunciados de gêneros publicados em edições, números ou datas diferentes, do mesmo jornal ou revista online, com a restrição de as réplicas obedecerem a certa periodicidade, para que a ressonância 
discursiva esteja assegurada. A seguir apresentamos exemplos que demonstram as relações dialógicas do ombudsman com os enunciados de diferentes gêneros do jornal:

a) No Editorial do Jornal da Manhã de 16 de dezembro de 2008 é dito:

\section{O presidente e os recordes de aprovação do governo}

O caso de Lula é fantástico, do posto de vista da análise política.

Depois do sufoco que passou no primeiro mandato, com o episódio do 'mensalão', entre outros, o presidente parecer aprendido a lição. Fez uma 'faxina' no governo, se afastou de algumas das más companhias (como José Dirceu e José Genoíno) e mostrou mais trabalho para a população, apostando pesado nos dois programas que são os carroschefes do governo: Bolsa Família e PAC (Programa de Aceleração do Crescimento) (Jornal da Manhã, 16 de dezembro de 2008).

Esse é homem que nasceu pobre, tornou-se político de direita e se aliou aos burgueses neoliberais para ser para o líder de todos. (Jornal da Manhã, 16 de dezembro de 2008).

No espaço Comentários, o leitor critica o editorial quanto aos erros de português, em uma relação dialógica de réplica ao já-dito:

\section{COMENTÁRIOS}

[Adão Aguiar de Oliveira]

Meu comentário seria para que houvesse uma revisão do texto mais criteriosa. No seguinte parágrafo parece me faltar um verbo: 'Depois do sufoco que passou no primeiro mandato, com o episódio do 'mensalão', entre outros, o presidente parecer (ter) aprendido a lição'. e neste outro: 'Esse é homem que nasceu pobre, tornou-se político de direita e se aliou aos burgueses neoliberais para ser PARA o líder de todos.' (Jornal da Manhã, 16 de dezembro de 2008).

Finalmente, esses enunciados são o mote dos comentários do ombudsman, estabelecendo relação dialógica de réplica/tréplica do ombudsman com os já-ditos (jornal e leitor).

\section{Pedido do leitor}

Essa semana, o comentário do leitor Adão Aguiar de Oliveira reflete sobre isso. Ele diz que gostaria de ver no JM uma revisão do texto mais criteriosa e aponta algumas falhas no texto do Editorial de terçafeira. Na frase: 'Depois do sufoco que passou no primeiro mandato, com o episódio do 'mensalão', entre outros, o presidente parecer aprendido a lição'. Falta aí o verbo 'ter'. Em outra: 'Esse é homem que nasceu pobre, tornou-se político de direita e se aliou aos burgueses neoliberais para ser para o líder de todos'. Sobrou um 'para'. Indiscutivelmente, o erro de português ou de gramática é menos significativo que o de conteúdo. Entretanto, é o mais fácil de se notar (Jornal da Manhã - Espaço da Ombudsman, 21 de dezembro de 2008).

Nesse exemplo, o autor, primeiramente, assimila o já-dito, o discurso de um leitor, e, num ato de concessão, parece se assimilar ao seu discurso (movimento dialógico de 
assimilação, marcado pela expressão indiscutivelmente, que orienta para uma crítica ao jornal). Ao apresentar a opinião desse leitor específico, também se engaja com o leitor previsto e com o jornal, participante da interação, pois está incorporando positivamente um outro. Apesar desse efeito inicial de engajamento para com o leitor, o engajamento efetivo e a evidência de sua opinião para com o jornal são marcados pelo operador discursivo entretanto: "Indiscutivelmente, o erro de português ou de gramática é menos significativo que o de conteúdo. Entretanto, é o mais fácil de notar.”.

b) No título de texto legenda para foto da Folha de S. Paulo, que chama a matéria sobre a visita de Carla Bruni e Camila Pitanga a um banco de leite materno $^{30}$, encontra-se o seguinte enunciado verbal:

\section{MAMÃE, EU QUERO MAMAR}

A primeira-dama francesa, Carla Bruni, é acompanhada pela atriz Camila Pitanga durante visita ao banco de leite materno do Instituto Fernandes Figueira da Fiocruz, no Rio. (Folha de S. Paulo, 23 de dezembro de 2008).

Nos comentários do Painel do Leitor encontramos a seguinte réplica a esse já-dito:

\section{Primeira Página}

Desconcertante a chamada de capa da matéria da visita de Carla Bruni e Camila Pitanga ao banco de leite materno: 'Mamãe, eu quero mamar'. Não paro de me questionar por que as atitudes (qualquer atitude, mesmo as profissionais) de uma mulher bonita são exaustivamente remetidas a sua beleza - inclusive com expressões de conotação sexual. E se fosse o Brad Pitt visitando um banco de leite, ou de sangue, ou o que seja: a chamada remeteria a sua beleza física? Muito provavelmente não. Triste notar que a nossa imprensa ainda é tão machista.

SABINE RIGHETTI (São Paulo, SP)

(Folha de S. Paulo, 24 de dezembro de 2008).

Na edição do ombudsman seguinte, encontramos a réplica/tréplica do autor a esses jáditos:

\section{... E ONDE FOI MAL [o jornal] \\ Sexismo}

Título de texto-legenda para foto de Carla Bruni e Camila Pitanga na capa de terça faz brincadeira sexista, antiquada e sem graça com os atributos físicos das personagens

(Folha de S. Paulo - ombudsman, 28 de dezembro de 2008).

Nesse exemplo, o autor do ombudsman não cita o leitor direta ou indiretamente, mas há um índice de polifonia por conta do já-dito no Painel do leitor. Nota-se também o acento de valor negativo dado ao enunciado do jornal. O autor é incisivo em sua crítica,

\footnotetext{
${ }^{30} \mathrm{~A}$ chamada de capa dessa matéria não aparece na página inicial da Folha de S. Paulo em sua versão online. É possível visualizá-la no link do fac-símile da primeira página da versão impressa, que pode ser acessado na primeira página da versão online da Folha. Isso não compromete a análise das relações dialógicas do gênero em sua versão online porque, como o fac-símile está disponível, toda a observação pode ser realizada no ambiente virtual sem necessidade de recorrer à versão impressa.
} 
que se manifesta no próprio título da subseção da coluna “...E onde foi mal” e na gradação de adjetivos "sexista, antiquada e sem graça”.

Nos dados analisados, a relação dialógica que os autores do ombudsman estabelecem com os leitores, além do modo implícito, como destacado no exemplo acima, configurase através de citação direta ou indireta:

a) Exemplo de citação indireta do discurso do leitor:

Também é crescente o número de comentários sobre erros nos conteúdos de algumas reportagens. Sábado passado, José Antônio Chaves Vaz Júnior escreveu sobre a reportagem 'Pai de família mata esposa e foge', de Cotidiano. Segundo ele, o fato ocorreu na Vila Bertha e não no Davi Federmann como constava na matéria. Na terçafeira, a mesma editoria traz o título 'Bingo em igreja termina em morte na Vila Liane'. Celso Costa comentou que esteve na festa e o acontecimento foi no sábado à tarde e não no domingo, como dizia a reportagem. (Jornal da Manhã - Espaço da Ombudsman, 21 de dezembro de 2008).

b) Exemplo de citação direta do discurso:

Ainda esta semana, vários leitores se queixaram da avaliação da Folha sobre como o STF decidiria o caso Raposa/ Serra do Sol. 'Tudo levava a crer que o resultado seria muito diferente do que ocorreu', reclamou Sérgio Alexandre Antunes de Carvalho, por exemplo. (Folha de S. Paulo - ombudsman, 14 de dezembro de 2008).

Notamos, igualmente, a relação dialógica com os enunciados publicados no jornal e o modo como são enquadrados e valorados quando citados pelo ombudsman:

'Seis morrem em colisões na região' é o título da matéria de Cotidiano, terça-feira. Mas a reportagem começa assim: 'O fim de semana foi trágico no trânsito da região com cinco vítimas fatais (...)’. No texto sim, aparecem seis vítimas. (Jornal da Manhã - Espaço da Ombudsman, 30 de dezembro de 2008).

Como bem realçou o editorial deste jornal no domingo passado, 'não existe ponto nesse documento histórico que não seja cotidianamente desrespeitado na esmagadora maioria dos países do mundo', mas 'considerar que a Carta da ONU consiste apenas numa peça de ficção seria uma maneira sutil de desqualificar o seu sentido mais profundo'. (Folha de S. Paulo - ombudsman, 21 de dezembro de 2008).

Além da relação dialógica mais constante entre leitor, jornal e autor, notamos a presença e o enquadramento de outras vozes que estão fora dessa tríade.

Será que a tomada de posse pela terceira vez não seria o momento para voltar ao assunto? Um release da assessoria de imprensa da prefeitura, de maio de 2008, falava do início das obras em 4 de junho. Aqui, um trecho que fala do prazo para conclusão da obra: 'A estimativa do governo é de que os serviços sejam concluídos num prazo máximo de seis meses. Para alcançar esse prazo, e em virtude da 
demora no início das obras, em função de atrasos decorrentes de problemas burocráticos e legais, as obras serão executadas inclusive aos sábados, domingos e feriados’(Jornal da Manhã - Espaço da Ombudsman, 09 de janeiro de 2009).

Um debate sobre a Ilustrada, publicado anteontem, foi dominado por lembranças de como ela era comentada nos anos 1980, e não é mais.

O próprio livro oficial comemorativo dos 50 anos transpira saudosismo. Já no segundo parágrafo da apresentação, cita o diretor de teatro Gerald Thomas: 'A Ilustrada foi a internet da década de 80’.(Folha de S. Paulo - ombudsman, 14 de dezembro de 2008).

Nesse exemplo, percebemos o acento de valor negativo dado ao discurso citado que se configura na introdução da citação, por meio de "transpira saudosismo". Para Bakhtin (1986 [1929], p. 144, grifos do autor): "O discurso citado é o discurso no discurso, a enunciação na enunciação, mas é, ao mesmo tempo, um discurso sobre o discurso, uma enunciação sobre a enunciação". Quando o autor cita direta ou diretamente outros discursos, ele o faz axiologicamente, dando um novo acento à voz incorporada para valorá-la positivamente com o seu ou com um outro discurso. A citação direta ou indireta da voz do leitor é acompanhada por acentos de valor brandos ou positivos; já o jornal, em seu modo de atuar, ou as vozes que escapam à tríade jornal, autor e leitor são, na maioria das vezes, acentuados negativamente.

\subsection{0 projeto discursivo}

A investigação do projeto discursivo requer observar os objetivos do gênero no espaço do jornalismo. A finalidade intrínseca ao gênero ombudsman é a crítica ao jornalismo e ao próprio jornal como um todo (ou o efeito de crítica) em seu modo de tratar os diversos temas abordados. Nesse sentido, os leitores exercem uma função importante, pois suas sugestões e reclamações orientam o autor em seu projeto discursivo.

A escolha do objeto do discurso pelo autor é fortemente regulada pelo gênero. Como dito, o jornalismo e o próprio jornal em que se encontra o gênero são tais objetos. Acreditamos, portanto, que os autores dificilmente venham a abordar constantemente outros assuntos que não tenham associação com o objeto do discurso do gênero. Em contrapartida, a atividade jornalística e os jornais enquanto veículos de informação variam muito em termos de assuntos e suas consequentes abordagens, que podem ser discutidas e criticadas.

O autor do ombudsman dirige-se a um leitor previsto. Além daquilo que é efetivamente enunciado pelos leitores, ou seja, suas reclamações e sugestões, o cálculo da possível resposta do leitor também determina a escolha do que vai ser tratado na coluna. Obviamente, a vontade discursiva do autor do ombudsman se concretiza também pelo modo como ele se posiciona e não só pelo que ele escolhe tratar. Esse posicionamento tem relação estreita com o leitor previsto do gênero, que quer ser defendido ou que reivindica uma resposta a seus questionamentos. Na busca dessa defesa, há, por parte do autor do ombudsman, a crítica do jornalismo e da empresa jornalística quanto às suas abordagens, bem como uma escolha de assuntos associados que em si são delicados. Como visto nos estudos da autoria e das relações dialógicas, a posição responsiva 
discordante dos autores do gênero em relação ao jornalismo e à empresa jornalística tem um aparente efeito de ser enérgica, cumprindo a função de apontar problemas e defeitos que podem ser indicados também pelos leitores. Ao mesmo tempo, o acento valorativo para o discurso enquadrado do leitor tende à positividade, evidenciando mais uma vez a questão do leitor previsto para o qual se calcula o desejo de defesa, desejo de uma ética do jornalismo ou simplesmente de um jornal bem elaborado. Isso não quer dizer que o autor do ombudsman não discorde do leitor ou concorde com os enunciados do jornal. Porém, em casos desse disso tipo, ele tende a ser mais discreto, ou minimiza a crítica do leitor. A aparente contundência das críticas direcionadas ao jornal e esse projeto ou vontade de defesa do leitor fazem com que o discurso refratado pelo gênero produza um efeito de autonomia do ombudsman, como se o autor tivesse liberdade total para se posicionar. Sobre essa questão, conversamos com Elaine Javorski, ombudsman do Jornal da Manhã:

Autores do artigo: Você tem total autonomia na elaboração da sua coluna? Há restrições do jornal sobre o que você aponta em seus textos?

Elaine: Tenho total autonomia. Meu texto passa sim por uma revisão, mas é apenas uma revisão de erros de ortografia, digitação, etc. Não se mexe no conteúdo.

O que se deve questionar no momento é se não há uma escolha tendenciosa dos assuntos por parte do autor do ombudsman. Isto é, mesmo com a visível defesa do leitor e a crítica ao jornal ou à empresa jornalística, o autor do ombudsman poderia prever aquilo que o jornal viria a interditar, ainda que não haja uma revisão de conteúdo como afirma Elaine Javorski. Reiteramos que a liberdade discursiva do ombudsman é mais um efeito de autonomia total do que a autonomia total propriamente dita. A autonomia (e seu limite) é permitida e autorizada pelo jornal enquanto empresa. E se é feito desse modo, é porque é bom para o veículo. Cabe-nos então tentar demarcar até que ponto, de fato, vai a independência do autor do ombudsman. Podemos apontar que o seu limite discursivo está associado ao projeto mercadológico do jornal. As críticas podem ser ásperas, e os limites para o posicionamento dos autores, elásticos, desde que não se atinja uma gravidade tal que venha a ameaçar as vendas e a posição do veículo no mercado. Assim, podemos concluir que a intenção discursiva dos autores do gênero é atendida em parte, porque há sim alguma liberdade, mas essa não deve ameaçar a posição ideológica do jornal como empresa, que necessita escoar o seu produto.

Portanto, o limite da liberdade e da autonomia do autor pode estar na omissão de assuntos que possam ir de encontro às posições do jornal. Segundo Mendes (2002, p.61), às vezes, pode haver alguma omissão: “Apesar da função contribuir para uma atuação mais ética dos meios de comunicação, isso não quer dizer que não ocorram casos em que o ombudsman vai se omitir (intencionalmente ou não) e deixará de defender importantes interesses do público”. O autor também expõe a possibilidade de desavenças internas com resultados graves que, evidentemente, terão reflexo no discurso do ombudsman e nas suas críticas ao jornal: "As faces dolorosas do trabalho do ombudsman são as represálias que sofre da redação, da direção do jornal e, até mesmo, de outros meios de comunicação" (MENDES, 2002, p. 48). Uma grande ameaça ao projeto mercadológico do jornal, por exemplo, pode vir a ser algo silenciado. Logo, critica-se o que é permitido criticar. Portanto, a liberdade axiológica do ombudsman está 
marcada e assegurada também pelo discurso do silêncio, e a liberdade discursiva, de fato, é um efeito de sentido.

Cabe-nos ainda investigar por que motivos os jornais analisados mantêm o gênero ombudsman. Há que se considerar as finalidades mercadológicas do jornal. Aqui estamos nos referindo ao jornal como empresa, que necessita vender bem seu produto, e para isso define objetivos. No que concerne ao cargo e não ao gênero, a figura do ouvidor, antes mais relacionada à esfera dos serviços públicos, começou a adentrar também a esfera da iniciativa privada ${ }^{31}$. Vismona (2000) explica que um dos motivos para o desenvolvimento da função na iniciativa privada foi o fortalecimento da defesa do consumidor dentro dessa esfera. A empresa passa a enxergar a presença do ombudsman como mais um artifício para evitar conflitos ou mesmo apaziguar os já instaurados. Isso preveniria dispêndios resultantes da ação de indivíduos que se sentissem de algum modo lesados e recorressem ao código de defesa do consumidor. Outro motivo para a presença do ombudsman na esfera privada é a manutenção da imagem da empresa. Diríamos que o ombudsman não é necessariamente um artifício de marketing, mas pode contribuir para o aspecto mercadológico. Para Vismona (2000, p.11, grifos nossos):

[...] identificaram no Ombudsman um canal importante de comunicação direta com o consumidor, conferindo uma maior transparência às suas atividades. Assim a empresa obteria uma presença mais satisfatória e diferenciada junto ao seu mercado, aperfeiçoando a qualidade de seus produtos e serviços.

O ombudsman no jornalismo também vem a contribuir para os objetivos de mercado do jornal enquanto empresa. Isso vale tanto para o cargo quanto para o gênero, mas o segundo tem um papel essencial. Se os profissionais que ocupam o cargo nos jornais selecionados exercem a função de ouvidor independentemente da existência do gênero, é a publicação semanal das colunas que mais oferece a um público amplo a possibilidade de saber que esses veículos mantêm esse serviço. É claro que para atender os fins mercadológicos, o gênero ombudsman não é a única nem a principal “estratégia”, mas a sua publicação encerra uma considerável fração de importância. Na análise dos horizontes espacial e temporal, dissemos que o destaque da coluna do ombudsman dado pelo Jornal da Manhã em sua página inicial concede certa credibilidade ao gênero. O contrário também é verdadeiro: a presença do gênero dá credibilidade ao jornal, pois produz um efeito de responsabilidade do veículo. Os discursos dos jornais acentuam a presença do gênero/função positivamente. Inclusive o Jornal da Manhã, em seu mídia kit ${ }^{32}$, conjunto de informações destinadas aos anunciantes, logo no início do texto, destaca a presença do ombudsman como um diferencial do veículo:

A preocupação com a opinião do leitor é outro diferencial do Jornal da Manhã. Além de espaços específicos para que o leitor possa manifestar o seu ponto de vista - através de comentários, artigos ou

\footnotetext{
${ }^{31}$ Aqui nesse contexto estamos tomando o termo esfera privada como trabalho da iniciativa privada e não no sentido do Círculo de Bakhtin,como esfera íntima.

${ }^{32}$ Disponível em <http://www.jmnews.com.br/portal/objetos/midiakit/apresentacao/perfil_jm.pdf>. Acesso em: 14 de dezembro de 2008.
} 
mesmo assumindo a função de 'repórter' - o JM possui um 'ombudsman' que exerce, portanto, o papel de 'ouvidor' ou 'advogado do leitor', saindo em defesa de quem, diariamente, fica informado através das páginas do jornal.

Como os anunciantes são o interlocutor previsto do mídia kit, fica evidente a ideia que o jornal tem o ombudsman como uma presença positiva em sentido mercadológico. A Folha de S. Paulo também produz uma valoração positiva sobre tal presença. Na página de apresentação do ombudsman em sua versão online ${ }^{33}$, é destacado o fato de a Folha ter sido o primeiro jornal brasileiro a adotar a função, em 1989. Embora as referências dos jornais sejam ao cargo, é improvável que no meio jornalístico o termo ombudsman soe tão polifonicamente como no campo do estudo sociodialógico, não havendo assim uma delimitação contundente entre a função interna, o jornal e o gênero. No jornalismo, com base nos dados e fontes analisados, referir-se à figura do ouvidor implica considerar o gênero. Além disso, é o gênero que concede uma fração relevante da visibilidade do cargo.

O gênero ombudsman e os resultados positivos de sua manutenção pelo jornal sobrevivem da contradição. A abordagem jornalística é, até certo ponto, questionada, julgada e publicizada, evidenciando problemas que os leitores sozinhos, provavelmente, nem sempre identificariam. De qualquer modo, o julgamento negativo do jornal por parte do autor do ombudsman pode, ao invés de denegrir o veículo, produzir um efeito de sentido de responsabilidade, transparência, ética ou compromisso por parte do próprio jornal, já que este último permite a presença de uma fonte de crítica. Isso não quer dizer que o jornal não tente realmente melhorar em qualidade, como se o gênero existisse somente para provocar um efeito de responsabilidade, ao invés da responsabilidade de fato. Deve-se levar em conta que, para uma empresa, um ato responsável efetivo tem seu reflexo no mercado. Se o gênero ombudsman pode ser um "termômetro" da responsividade dos leitores, o jornal que o acomoda pode mais ou menos apreender o conceito de responsabilidade ou ética que o seu público tem e orientar-se a partir disso. Para tanto, uma pesquisa de mercado pode ser mais eficaz, mas não anula a relevância do ombudsman, que, nesse sentido, é fundamental para os fins da empresa jornalística entre eles, os mercadológicos.

Em síntese, consideramos que o projeto discursivo do autor do ombudsman, sua vontade de dizer, está ligado a dois fatores. A finalidade intrínseca ao gênero ombudsman é a crítica ao jornalismo. O primeiro fator seria então o leitor previsto que força a crítica. $\mathrm{O}$ segundo é o projeto ideológico/mercadológico da empresa jornalística. A crítica não deve gerar posições valorativas que contrariem ou ameacem esse projeto. Haveria um limite para o julgamento. A vontade de dizer do autor do ombudsman não se realizaria absolutamente. Está limitada e subjugada pelo projeto maior da empresa jornalística, que é a venda de seu produto, o jornal. Nesse aspecto, a presença do gênero não pode ser desfavorável ao veículo jornalístico. Há, nesse caso, uma relação verticalizada, ainda que o efeito de autonomia do autor do gênero seja expressivo.

\footnotetext{
${ }^{33}$ Disponível em: < http://www1.folha.uol.com.br/folha/ombudsman/>. Acesso em: 26 de dezembro de 2008.
} 


\section{CONSIDERAÇÕES FINAIS}

Como resultados da análise do gênero ombudsman, destacamos, dentre outros aspectos:

a) A periodicidade semanal.

b) O jornal onde o gênero se expressa e a atividade jornalística como objetos do discurso e dos sentidos.

c) O endereçamento ao leitor, com vistas a atender as suas reivindicações.

d) O movimento dialógico de assimilação; a principal voz incorporada é a voz do leitor.

e) O movimento dialógico de engajamento para com o leitor previsto/geral do gênero, com vistas a sua adesão ao discurso do ombudsman e do jornal.

f) Acento de valor positivo ou brando, quando crítico, para o discurso do leitor.

g) Acento de valor negativo (ou seu efeito), de um modo geral, para a cobertura jornalística objeto de discussão.

h) Relação dialógica fortemente marcada entre leitor, jornal e autor.

i) Materialização na textualização do gênero das críticas dos leitores de modo implícito ou na forma de citação direta ou indireta.

j) Projeto discursivo limitado pelo projeto ideológico/mercadológico da empresa jornalística.

À realização desse artigo não coube a pretensão de exaurir a análise dos dados e apresentar uma análise fechada/acabada das regularidades do gênero ombudsman e, com isso, formular e apresentar uma definição acabada do gênero estudado. Em primeiro lugar, porque isso iria de encontro à concepção Bakhtinana de estabilidade relativa do gênero. Se, afinal, há uma indicação de relatividade, é porque os enunciados regulados por um determinado gênero precisam ser entendidos em relação a sua dialogicidade, natureza esta que impede um fechamento absoluto em categorias totalmente estáveis e padronizadas sem relação com as dimensões social e histórica e o seu devir. Rodrigues (2005) esclarece a noção de gênero em Bakhtin, transcendendo a ideia de cristalização dos enunciados:

Analisando o desenvolvimento conceitual dos gêneros em Bakhtin, pode-se dizer que sua noção de gênero como tipo de enunciado não é a das seqüências textuais, nem o resultado de uma taxionomia ou princípio de classificação científica, mas uma tipificação social dos enunciados que apresentam certos traços (regularidades) comuns, que se constituíram historicamente nas atividades humanas, em uma situação de interação relativamente estável, e que é reconhecida pelos falantes. (RODRIGUES, 2005, p.164)

Portanto, estamos longe de vislumbrar o estudo e seus resultados como uma produção hermética e definitiva, mas sim como uma investigação de algumas regularidades do gênero estudado. A caracterização aqui proposta não é conclusiva. 
Em segundo lugar, porque a análise é sempre marcada pelos objetivos propostos e situada cronotopicamente, o que requer e permite outros olhares, novos aprofundamentos, com uma nova amplitude do objeto de pesquisa, que podem vir a apresentar outras regularidades do gênero ombudsman. Além da perspectiva teórica em que nos apoiamos, o próprio gênero que acolhe nosso discurso, o artigo científico, de certo modo, também direciona a análise dos dados. Entendemos, então, este trabalho, como parte de um percurso a ser complementado, como, por exemplo, pode-se observar nos outros artigos deste número, que apresentam a análise do gênero a partir de outros fundamentos teóricos.

\section{REFERÊNCIAS}

AMARAL FILHO, Marcos João Teixeira do. O ombudsman e o controle da administração. São Paulo: Editora da Universidade de São Paulo, 1993.

BAKHTIN, M. (VOLOCHINOV). Marxismo e filosofia da linguagem. 3. ed. São Paulo: HUCITEC, 1986 [1929].

. Para uma filosofia do ato. Tradução, para fins didáticos, de Carlos Alberto Faraco e Cristóvão Tezza da edição americana Toward a philosophy of the act. Austin, University of Texas, 1993. [1919-1921] s.d.

Problemas da poética de Dostoiévki. 2. ed. Rio de Janeiro: Forense Universitária, 1997 [1929].

Estética da criação verbal. São Paulo: Martins Fontes, 2003[1979].

DORNELLES, Alexandre Borges. O Ombudsman no Brasil: mito ou realidade. Revista Jurídica da Unisul. Tubarão, v.2, n.1, p. 29-37,ago.2000.

JAKOBSON, R. Linguística e comunicação. São Paulo: Cultrix, 1970.

MENDES, Jairo Faria. O ombudsman e o leitor. Belo Horizonte: Editora O Lutador, 2002.

RODRIGUES, Rosângela Hammes.Os gêneros do discurso na perspectiva dialógica da linguagem: a abordagem de Bakhtin. In: MEURER, José Luiz; BONINI, Adair; MOTA-ROTH, Désirée. (Orgs.). Gêneros: teorias, métodos e debates. São Paulo: Parábola Editorial, 2005. p. 152-183.

VISMONA, Edson Luiz. A Ouvidoria no Brasil e seus Princípios. In: ASSOCIAÇÃO BRASILEIRA DOS OUVIDORES. A ouvidoria no Brasil. São Paulo: Imprensa Oficial do Estado, 2000. p.11-20. 


\section{REFERÊNCIAS DOS DADOS DE PESQUISA}

\section{Jornal da Manhã de Ponta Grossa - versão - online:}

FREITAS, Ismael de. Pacientes sofrem sem atendimento. Jornal da Manhã, Ponta Grossa, 10 de dezembro de 2008. Disponível em:

$<$ http://www.jmnews.com.br/index.php?setor=NOTICIAS\&nid=199631>. Acesso em: 14 de dezembro de 2008.

JAVORKSY, Elaine. Histórias e Personagens. Jornal da Manhã- Espaço da ombudsman, Ponta Grossa, 14 de dezembro de 2008. Disponível em: $<$ http://www.jmnews.com.br/index.php?setor=NOTICIAS\&nid=209531 >. Acesso em: 14 de dezembro de 2008.

. Revisar para não errar. Jornal da Manhã- Espaço da ombudsman, Ponta Grossa, 21 de dezembro de 2008. Disponível em:

$<$ http://www.jmnews.com.br/index.php?SETOR=COLUNA\&CID=89\&POST=39282

$>$. Acesso em: 21 de dezembro de 2008.

Os balanços de 2008. Jornal da Manhã - Espaço da ombudsman, Ponta

Grossa, 30 de dezembro de 2008. Disponível em:

$<$ http://www.jmnews.com.br/index.php?SETOR=COLUNA\&CID=89\&POST=40022> . Acesso em: 30 de dezembro de 2008.

\begin{tabular}{lcllll} 
& Sete desejos para & 2009. Jornal da Manhã - Espaço da ombudsman, Ponta \\
\hline Grossa, & 09 & de & dezembro de 2009. & Disponível em:
\end{tabular} $<$ http://www.jmnews.com.br/index.php?SETOR=COLUNA\&CID=89\&POST=41142>. Acesso em: 09 de dezembro de 2009.

JORNAL DA MANHÃ. Mídia Kit. Ponta Grossa, s.d. Disponível em: $<$ http://www.jmnews.com.br/portal/objetos/midiakit/apresentacao/perfil_jm.pdf $>$. Acesso em: 14 de dezembro de 2008.

JORNAL DA MANHÃ. Editorial: O presidente e os recordes de aprovação do governo. Ponta Grossa, 16 de dezembro de 2008. Disponível em: $<$ http://www.jmnews.com.br/index.php?setor=NOTICIAS\&nid=213331 > . Acesso em: 21 de dezembro de 2008.

OLIVEIRA, Adão Aguiar de. Jornal da Manhã - Comentários, Ponta Grossa, 16 de dezembro de 2008. Disponível em:

$<$ http://www.jmnews.com.br/index.php?setor=NOTICIAS\&nid=213331 $>$. Acesso em: 21 de dezembro de 2008.

\section{Jornal da Manhã de Ponta Grossa - versão digital:}

JAVORKSY, Elaine. Histórias e Personagens. Jornal da Manhã - Espaço da ombudsman, Ponta Grossa, 14 de dezembro de 2008. Disponível em: 
$<$ http://www.jmnews.com.br/index.php?setor=JMDIGITAL\&cdid=1>. Acesso em: 14 de dezembro de 2008.

Jornal Folha de S. Paulo - versão - online:

CABRAL, Maria Clara. Ampliação do Supersimples é aprovada. Folha de S. Paulo Dinheiro, 11 de dezembro de 2008. Disponível em: $<$ http://www1.folha.uol.com.br/fsp/dinheiro/fi1112200845.htm>. Acesso em: 14 de dezembro de 2008.

FOLHA DE S. PAULO. O que é o cargo? São Paulo, 2008. Disponível em: $<$ http://www1.folha.uol.com.br/folha/ombudsman/cargo.shtml $>$. Acesso em: 14 de dezembro de 2008.

FOLHA DE S. PAULO. Fac-símile da capa da edição de 23/12/2008. São Paulo, 23 de dezembro de 2008. Disponível em:

$<$ http://www1.folha.uol.com.br/fsp/cp23122008.htm>. Acesso em: 28 de dezembro de 2008.

GUIMARÃES, Larissa. Com novas emendas, Senado aprova cota da meia-entrada. Folha de S. Paulo-Ilustrada, 10 de dezembro de 2008. Disponível em: <http://www1.folha.uol.com.br/fsp/ilustrad/fq1012200835.htm> Acesso em: 14 de dezembro de 2008.

MOTA, Vinicius. Leitor tem renda e escolaridade altas. Folha de S. Paulo - Tudo sobre a Folha. São Paulo, s.d. Disponível em:

$<$ http://www1.folha.uol.com.br/folha/80anos/quem_e_o_leitor.shtml $>$.Acesso em: 21 de dezembro de 2008.

RIGHETTI, Sabine. Primeira Página. Folha de S. Paulo - Painel do Leitor. São Paulo, 24 de dezembro de 2008. Disponível em:

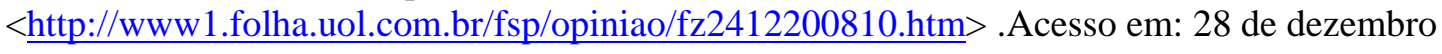
de 2008.

Textos da coluna do ombudsman do dia 14 de Dezembro de 2008:

.AVISO. Folha de S. Paulo - ombudsman, 14 de dezembro de 2008. Disponível em: <http://www1.folha.uol.com.br/fsp/ombudsma/om1512200801.htm>. Acesso em: 14 de dezembro de 2008.

SILVA, Carlos Eduardo Lins da. Muitas outras águas vão rolar. Folha de S. Paulo ombudsman, 14 de dezembro de 2008. Disponível em:

$<$ http://www1.folha.uol.com.br/fsp/ombudsma/om1412200801.htm>. Acesso em: 14 de dezembro de 2008.

. Vocês querem bacalhau? Folha de S. Paulo-ombudsman, 14 de dezembro de 2008. Disponível em: 
< http://www1.folha.uol.com.br/fsp/ombudsma/om1412200802.htm>. Acesso em: 14 de dezembro de 2008.

Para Ler. Folha de S. Paulo-ombudsman. 14 de dezembro de 2008.

Disponível em: <http://www1.folha.uol.com.br/fsp/ombudsma/om1412200803.htm>. Acesso em: 14 de dezembro de 2008.

Textos da coluna do ombudsman do dia 21 de dezembro de 2008:

SILVA, Carlos Eduardo Lins da. Jornalismo e direitos humanos. Folha de S. Paulo ombudsman, 21 de dezembro de 2008. Disponível em:

$<$ http://www1.folha.uol.com.br/fsp/ombudsma/om2112200801.htm>. Acesso em: 21 de dezembro de 2008.

. Santa Catarina não é nem Rio nem Tailândia. Folha de S. Paulo-ombudsman,

21 dezembro de 2008. Disponível em:

$<$ http://www1.folha.uol.com.br/fsp/ombudsma/om2112200802.htm>. Acesso: 21 de dezembro de 2008.

Para Ler. Folha de S. Paulo - ombudsman, 21 de dezembro de 2008.

Disponível em: <http://www1.folha.uol.com.br/fsp/ombudsma/om2112200803.htm>. Acesso em: 21 de dezembro de 2008.

Textos da coluna do ombudsman do dia 28 de dezembro de 2008:

SILVA, Carlos Eduardo Lins da. Ave Jano! 12 desejos para 2009. Folha de S. Paulo ombudsman, 28 de dezembro de 2008. Disponível em:

<http://www1.folha.uol.com.br/fsp/ombudsma/om2812200801.htm>. Acesso em: 28 de dezembro de 2008.

Para Ler. Folha de S. Paulo - ombudsman, 28 de dezembro de 2008.

Disponível em: <http://www1.folha.uol.com.br/fsp/ombudsma/om2812200802.htm>

Acesso em: 28 de dezembro de 2008.

Textos da coluna do ombudsman do dia 04 de janeiro de 2009:

SILVA, Carlos Eduardo Lins da. Quando é preciso chocar sem morbidez. Folha de S. Paulo - ombudsman, 04 de janeiro de 2009. Disponível em:

$<$ http://www1.folha.uol.com.br/fsp/ombudsma/om0401200901.htm> Acesso em: 04 de janeiro de 2009.

Dois jornais, dois juízes e suas diferenças. Folha de S. Paulo - ombudsman, 04 de janeiro de 2009. Disponível em:

<http://www1.folha.uol.com.br/fsp/ombudsma/om0401200902.htm> Acesso em: 04 de janeiro de 2009. 
Para Ler. Folha de S. Paulo - ombudsman, 04 de janeiro de 2009. Disponível em: $<$ http://www1.folha.uol.com.br/fsp/ombudsma/om0401200903.htm> Acesso em: 04 de janeiro de 2009. 